\title{
The impact of pensions, transfers and taxes on child poverty in Europe: the role of size, pro-poorness and child orientation
}

\author{
Ron Diris, $^{1, *}$ Frank Vandenbroucke ${ }^{2}$ and Gerlinde Verbist ${ }^{3}$ \\ ${ }^{1}$ Department of Economics, Maastricht University, Tongersestraat 53, 6200 MD Maastricht, The \\ Netherlands; ${ }^{2}$ University of Amsterdam, Spui 21, 1012 WX Amsterdam, The Netherlands and \\ ${ }^{3}$ Centre for Social Policy Herman Deleeck, University of Antwerp, St. Jacobsstraat 2, 2000 \\ Antwerp, Belgium
}

*Correspondence: r.diris@maastrichtuniversity.nl

\begin{abstract}
We assess the impact of redistributive policy on child poverty across 29 European welfare states, using EU SILC 2005-2012. We distinguish between spending on pensions, spending on other cash transfers and taxation. For each of these instruments of redistribution, we further distinguish three features: size, pro-poorness and targeting towards households with children. Pensions are generally neglected in analyses on child poverty, but are relevant through the presence of two, partially offsetting, forces. Increased pension spending weakens the relative income position of children, but pensions also substantially contribute to the household income of children from multigenerational households. This ambiguous result signals a challenge: while reductions in pension spending may be desirable in the long run in several European welfare states, policymakers-especially in Southern and Eastern Europe-should be aware that this not only directly involves income losses for the elderly, but also for a non-negligible share of (predominantly poor) children.
\end{abstract}

Key words: poverty, Europe, welfare state, redistribution, social policy

JEL classifications: H53 = Government Expenditures and Welfare Programs; 132 = Measurement and Analysis of Poverty; 138 = Government Policy • Provision and Effects of Welfare Programs

\section{Introduction}

Reducing child poverty rates is high on the political agenda across European welfare states. In addition to general concerns about the adverse consequences of high rates of poverty in society, child poverty is seen as especially alarming given its strong links to future measures 
of social progress and the vicious circle of disadvantage it can put families in. ${ }^{1}$ Traditionally, policy analyses of child poverty rates have focused on the role of benefits that are specifically directed towards working-age families or families with children in particular; see e.g. Förster and Tóth (2001), Chen and Corak (2008), and Adamson (2012). Typically, the role of pensions is neglected in such analyses, as pensions are targeted (virtually) exclusively to the elderly and therefore argued to be irrelevant for the poverty risk of children. Whenever pensions are discussed in relation to child poverty, this typically occurs in the context of potential indirect consequences, such as crowding-out effects; see e.g. Esping-Andersen and Sarasa (2002). However, pensions are also directly relevant for child poverty rates, for two particular reasons: they influence the relative income position of households with children, and they provide direct income support for children in three-generational households.

The aim of this article is to assess the multifaceted impact of redistributive policy on child poverty, with a particular focus on the role of pension spending. We characterize redistributive policy on the basis of three factors: size, pro-poorness (PP, or progressivity) and the degree of targeting towards households with children ('children's share' or CS). We apply this characterization separately to spending on pensions, spending on all other cash transfers and taxation. The CS measures are relevant because they directly affect the relative income position of children, and thus child poverty. The nature of their impact is expected to be different for pensions (for which they capture the share of pension benefits that is distributed to household where children live) on the one hand and other cash transfers on the other hand. As such, the distinction between the types of social spending is crucial. The empirical approach exploits changes in poverty ${ }^{2}$ and redistributive policy within countries over time. Using EU SILC 2005-2012 for the EU27 and Iceland and Norway, we estimate a generalized least squares (GLS) model containing our characterization of redistributive policy as well as other country characteristics and country and time fixed effects. Our analysis focuses on redistribution but we take measures of employment, demographics, labour market characteristics, macroeconomic indicators and education into account, as they can potentially confound the estimates of redistribution.

The article is organized as follows. We introduce theoretical considerations in Section 2, while methodological issues are discussed in Section 3. Section 4 presents the data. Results of the empirical analysis are discussed in Section 5. Section 6 concludes.

\section{Framework and methodology}

\subsection{The concept of child poverty}

Our main outcome measure is the at-risk-of-poverty rate, measured for individuals under the age of 18 (further referred to as 'children'), and based on a floating threshold of $60 \%$ of median equivalized household income. Relative poverty rates are closely related but conceptually different from measures of income inequality (e.g. Gini coefficients). First of all, their focus is on the lower half of the income distribution. Additionally, neither variation within the group that lives in poverty nor changes in income over time are reflected in a relative poverty measure. This is especially relevant given that the time frame we analyse incorporates the recent economic crisis, which led to severe income losses across the distribution.

1 See e.g. Heckman (2000), Duncan et al. (2011) and Cooper and Stewart (2013).

2 Throughout the rest of the article, 'poverty' refers to poverty among the population aged 0-17, based on a relative income threshold, unless otherwise indicated. 
We examine poverty based on household income, rather than material deprivation or any other measure that is (partly) based on consumption. We therefore exclusively focus on cash transfers as measures of social spending and ignore in-kind benefits. Similarly, when estimating the impact of taxation we focus on income taxes and ignore consumption taxes. Not taking into account in-kind benefits and VAT taxation can sketch a misleading picture when one would rank countries by level of child poverty, but such comparisons are not the purpose of this article.

Child poverty can be seen as the result of two components: the income distribution within the population of children and the average income position of children relative to the rest of the population. The role of the latter is often ignored but can be highly important. In fact, if all children are located in the upper half of the income distribution, child poverty would be zero, even when there would be considerable income variation within that group. Figure 1 shows the relative income position of children as well as child poverty rates that are based on a threshold that is calculated on the child population only rather than the population as a whole (labelled as 'within poverty'), across countries. The latter is essentially a measure of inequality among children within a certain country. Figure 1 shows that there are considerable differences in relative income positions, also for countries with similar levels of 'within poverty'. ${ }^{3}$ For example, within-poverty rates for Denmark and Austria are similar, but differences in relative income explain why their final poverty rates are almost 5 percentage points apart. Hence, the relative income position of children is a very relevant determinant of child poverty, which automatically implies that policies that affect this position also affect child poverty. Figure 2 shows the development of relative income and 'within poverty' over time. The crisis harmed the relative income position of children, which was followed by a modest recovery. One can presume that the relative stability of pensioners' incomes, compared to incomes of working-age households, plays a role here.

\subsection{The role of pension spending}

The relation between pension spending and child poverty is complex; our goal is to disentangle indirect and direct effects of pension spending and to show that the direct effect of pension spending operates via two, partially offsetting, mechanisms. Understanding these two direct mechanisms is important for an adequate calibration of reform policies.

With respect to the indirect effect of pension spending, both structural and cyclical impacts are relevant. High levels of pension spending may have a structural crowding-out effect, as they can reduce the capacity of governments to spend on other benefits and programmes, or can affect wage cost competitiveness. Pensions may also support effective demand and economic activity in times of crisis, and as such enhance the employment rate of families with children. Both this structural and cyclical indirect effect are controlled for in our empirical analysis, since spending on pensions, spending on other cash benefits and employment are simultaneously included as independent variables in our main estimation model. This allows us to focus on two direct impacts of pensions on child poverty. First, pension income is predominantly distributed to households without children; more generous pensions increase the poverty threshold and as such worsen the relative income position of children, all other things held equal. Secondly, a substantial share of three-generation

3 A broader analysis on the relative income positions of families with children versus childless families is provided by Bronchetti and Sullivan (2004). 


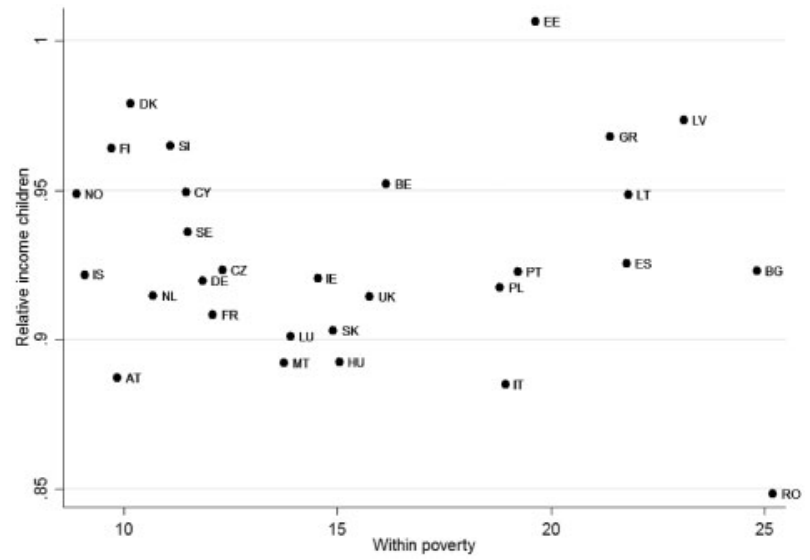

Figure 1. Relative income and within poverty: across countries.

Notes: 'Relative income children' divides mean equivalized household income for children by mean equivalized household income for the total population). 'Within poverty' measures child poverty based on a $60 \%$ threshold of median equivalized household income measured for the population of children only. Values are averaged for SILC 2005-2012.

Source: Own calculations based on EU SILC 2005-2012.

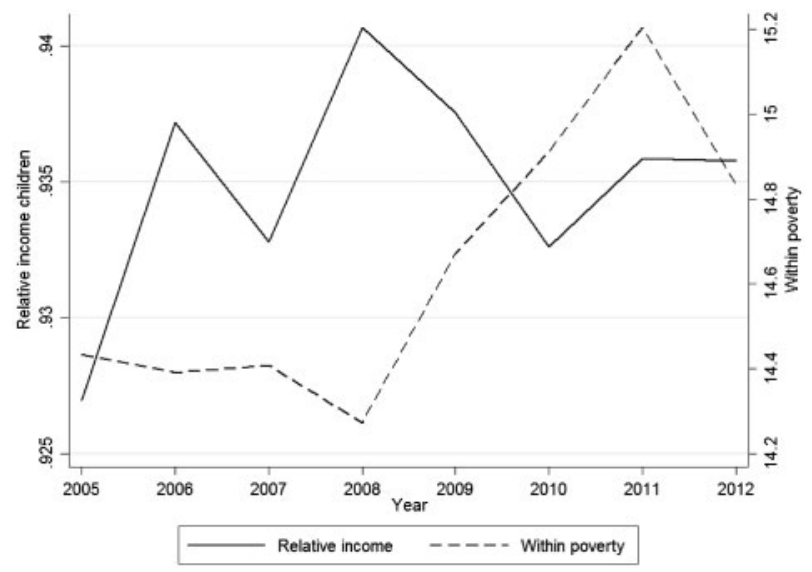

Figure 2. Relative income and within poverty: across time.

Notes: Averages are taken across countries with complete time series from 2005 to 2012. See Figure 1 for definitions of each variable.

Source: Own calculations based on EU SILC 2005-2012.

households in Southern Europe and Eastern Europe rely on pension income. Because these are generally poor households, pensions may substantially reduce inequality within the child population as well as increase the absolute standard of living of children. These two direct impacts of pension spending in relation to child poverty are typically neglected in empirical 
research. To gain insights into how each of these two mechanisms is influenced by redistribution, we use the previously defined 'within poverty' and relative income of children measures as separate outcome variables in the empirical analysis, in addition to child poverty. ${ }^{4}$

This analysis must be understood in the context of considerable diversity in the architecture of social spending across European countries, which is also reflected in stark differences in the prevalence of multigenerational households (i.e. households in which at least three generations live, abbreviated as 'MG households' for the remainder of the article) across European countries. It is plausible to argue that both differences in economic development across Europe as well as endogenous processes generated by inadequate welfare states are behind such differences. We examine the relative weight of the two direct impact mechanisms of pensions on child poverty, for the sample as a whole and also separately for countries with low and high shares of MG households. Our results underscore the fact that there is no 'one-size-fits-all' approach to welfare state reform in Europe, and that reform policies may be confronted with dilemmas in the short run. We further document this diversity in Section 4.1.

The analysis assumes that all resources are shared within the household. Previous research has rejected this 'classical' model of resource sharing. ${ }^{5}$ This rejection is generally based on analyses of traditional household structures, but likely applies to MG households as well. Albertini and Kohli (2012) show that financial transfers within extended families in Southern Europe are low and infrequent. However, the current study is not concerned with effective cash transfers between household members but rather with the extent to which household members contribute to the household budget. ${ }^{6}$ Additionally, findings from Duflo (2000) indicate that increased pension benefits in extended households benefit the development of children, while Hamoudi and Thomas (2005) show that the inclusion of elderly family members (which are typically grandmothers) in the household leads to a shift in bargaining power towards children's consumption. This indicates that at least a significant share of the extra pension income brought into the household is used for the benefit of children. In Section 5.7, we apply a sensitivity analysis to our results using different hypotheses with respect to sharing, and also examine data on reported levels of sharing in EU SILC.

On a related note, this study does not assess the role of inter-household transfers. Previous studies have found that transfers from parents to adult children are relatively common in Northern Europe, while relatively low in Southern Europe; see e.g Albertini et al. (2007) and Schenk et al. (2010). The data we use do not distinguish such transfers; they are incorporated in the overall household income. Inter-household transfers could be an additional mechanism in which households with children could benefit from pension income. Our separate estimations of the effects of redistribution by 'component' of child poverty and

4 Heuveline and Weinshenker (2008) have analysed the role of family structure in relation to child poverty, but without an explicit focus on the role of MG households and the corresponding source of pension income. Additionally, the broader intergenerational dimension of pension spending has been the subject of other research; see e.g. Esping-Andersen and Sarasa (2002), Tepe and Vanhuysse (2010) and Bradshaw and Holmes (2013).

5 See e.g. Schultz (1990), Thomas (1990) and Fortin and Lacroix (1997).

6 We note that extended family members can already reduce poverty risks by generating economies of scale. As equivalence scales increase less than proportionally with household size (which reflects economies of scale), (equivalized) household income increases when two families merge into one household, as this reduces the needs/resource balance in the household. 
the analysis by subsample can provide insights into the extent to which these transfers are relevant in our context.

For both pension and transfer spending, we distinguish size, PP and the share of benefits distributed to children. Previous literature has emphasized the importance of both size, see e.g. Notten and Gassman (2008), and of design, see e.g. Salanauskaite and Verbist (2013). PP has mainly been analysed in light of the contribution of Korpi and Palme (1998), who argue that spending size and PP are negatively related to each other. Since spending size is controlled for in our model, the results do not incorporate this potential interdependence. Research on more recent data does not find evidence of the Korpi-Palme paradox (Kenworthy, 2011; Marx et al., 2013). Our data support the factual conclusion of this recent research at the cross-sectional level, yet with important nuances. Space forbids this issue from pursuing in this article.

\section{Methodology}

We estimate the effects of several aspects of the tax-benefit system, while controlling for a range of other determinants of the at-risk of poverty rate for children (AROP). Our main model is specified as follows:

$$
\begin{gathered}
\mathrm{AROP}_{i t}=\alpha_{0}+\gamma^{\prime} \mathrm{PE}_{i t}+\beta^{\prime} \mathrm{TR}_{i t}+\vartheta^{\prime} \mathrm{Tax}_{i t}+\omega^{\prime} \mathrm{W}_{i t}+\lambda^{\prime} \mathrm{LM}_{i t}+\eta^{\prime} \mathrm{Macro}_{i t}+\sigma^{\prime} \mathrm{Skill}_{i t} \\
+\delta^{\prime} \mathrm{Demo}_{i t}+\mathrm{C}_{i}+\mathrm{T}_{t}+\varepsilon_{i t}
\end{gathered}
$$

The indicator $i$ identifies each country, while $t$ denotes the time period. Model 1 represents the full model, where vectors of pension spending $\left(\mathrm{PE}_{i t}\right)$, transfer spending $\left(\mathrm{TR}_{i t}\right)$, taxation $\left(\operatorname{Tax}_{i t}\right)$, household work intensity $\left(\mathrm{W}_{i t}\right)$, labour market characteristics $\left(\mathrm{LM}_{i t}\right)$, macro-economic indicators $\left(\mathrm{Macro}_{i t}\right)$, skill determinants $\left(\mathrm{Skill}_{i t}\right)$, demographics $\left(\mathrm{Demo}_{i t}\right)$ and time $\left(\mathrm{T}_{t}\right)$ and country $\left(\mathrm{C}_{i}\right)$ fixed effects are included. The vectors for transfer spending, pension spending and taxation contain three different measures that capture size, PP and child orientation. All indicators that are contained in each of the control vectors are described in Appendix Table A1. We select variables that have been shown to impact poverty rates in previous literature. ${ }^{7}$ Additional variables to those listed in Table A1 are tested as well but not included when they neither affect poverty nor the estimates for spending and taxation. ${ }^{8}$ By including unit fixed effects, we rely on variation within countries over time to estimate these impacts (similar to, for example, the empirical analysis in OECD (2011)). We choose this approach, since relying on cross-country variation can lead to biased estimates through the presence of structural country characteristics that relate to both redistribution and poverty and are often difficult to observe or measure. The unit fixed effects in our model are highly statistically significant, which underlines the importance of these structural factors and warrants the inclusion of country fixed effects. We estimate different reduced versions

7 We largely rely on seminal studies and overviews; see e.g. Bradley et al. (2003), Moller et al. (2003), Smeeding (2005) and OECD (2011).

8 This includes foreign direct investment, the share of single parent families, unionization and public sector size. Measures of minimum wage, replacement ratios and centrality of wage bargaining are only available for a limited sample; adding these variables to Model 1 for this reduced sample identifies a statistically significant effect only for centrality of wage bargaining, and none of the estimates for redistribution are affected (available on request). 
of Model 1, which gives an indication of the possible confounding effect of different groups of variables on the estimates for redistribution.

Previous literature on the relation between redistribution and child poverty has generally relied on static pre-post analyses that compare poverty rates with and without including benefits and taxes; see e.g. Levy et al. (2007), Matsaganis et al. (2007) and Salanauskaite and Verbist (2013), which contrasts with our fixed effects model. Our approach controls for a wide range of other country-level characteristics, as the determinants of poverty are often correlated with each other, which implies that omitting them can confound the estimates of the impact of redistribution. Most prominently, differences in employment levels are directly connected to the level of social spending through the existence of automatic stabilizers, which can lead to an underestimation of the impact of social spending (i.e. a positive bias in the coefficient on spending) when not accounted for. The methodological approach allows us to also incorporate behavioural responses to changes in redistribution (conditional on control variables).

A typical concern in empirical analysis using pooled cross-sectional data is misspecification of the error term. Based on formal tests (listed in Appendix Table A2), we correct for the presence of groupwise heteroscedasticity and serial correlation by specifying a GLS model with a heteroscedastic but uncorrelated error structure and an AR1 autocorrelation structure. ${ }^{9}$ Additionally, we conduct unit root tests, which reject non-stationarity. However, these tests are known for their lack of power (Maddala and Wu, 1999), and therefore we cannot fully rule out the presence of non-stationarity. When we include a lagged dependent variable in our model, the coefficient is statistically significant, although it is modest in magnitude (0.195). Section 5.7 addresses sensitivity to model specification, and refers to results for a first differences model and a lagged dependent variable model.

\section{Data}

Our analysis is predominantly based on micro-data from the EU Statistics on Income and Living Conditions (EU SILC) cohorts 2005-2012, from which we construct macro-level variables related to poverty and redistribution. SILC cohorts are based on information from the previous year, so this is essentially an analysis for the years 2004-2011. The UK and Ireland are exceptions, as their data refer to the labelled year. Since we control for year fixed effects and also use data sources other than SILC, we take this difference in setup into account by grouping all non-SILC measures not from Ireland and the UK under the year $\mathrm{T}+1$. The outcome variable 'child poverty' is based on a $60 \%$ threshold of median equivalized household income. For the construction of equivalent household income, we follow common practice in the EU and use the modified OECD equivalence scale, which attributes a weight of 1 to the first adult in the household, a weight of 0.5 to other individuals above age 15 and a weight of 0.3 to children of age 15 and younger.

\subsection{Spending size and CS}

As the poverty rate depends on inequality within the child population as well as the relative income position of children, we incorporate measures of both the size of transfer and

9 We rely on leading literature on panel data specifications, mainly Baltagi (1995), Kittel and Winner (2005) and Beck and Katz (2011). 


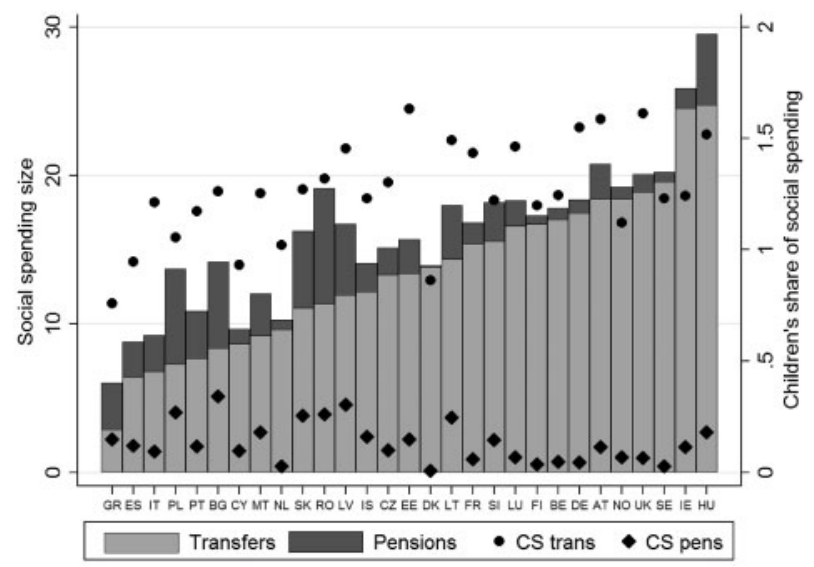

Figure 3. Spending size and CS: transfers and pensions.

Notes: 'Transfers' and 'pensions' measure average levels of spending distributed to those aged 0-17, for each type of benefit. These are expressed as a percentage of mean equivalized household income. 'CS trans' and 'CS pens' divide transfer and pension spending distributed to those aged 0-17 relative to the transfer and pension spending distributed to the population as a whole. All values are averaged over the EU SILC waves 2005-2012.

Source: Own calculations based on EU SILC 2005-2012.

pension spending towards the population as a whole and of the degree to which each type of spending is targeted towards children (CS). As a measure of the size of transfer (respectively pension) spending, we average total transfers (respectively pensions) received across households and express them as a share of the country's mean equivalized disposable income (we use 'spending size' as a shortcut). For the CS measures, we take the ratio of spending size (measured as defined before) distributed to those aged 0-17 divided by the spending size distributed to the population as a whole. It is assumed that all household income is equally shared, i.e. household income is the same for every individual within the same household. Transfers are defined as benefits for unemployment, sickness, disability, education, families and children, housing and non-elsewhere classified benefits. Pensions include old age and survivor benefits.

Figure 3 shows the average level of both transfer and pension spending distributed to those aged 0-17 for SILC 2005-2012, and also portrays the size of spending to those aged 0-17 relative to the spending towards the population as a whole. ${ }^{10}$ The ranking shows that low spending on cash transfers for children is especially prevalent in Southern European and Eastern European welfare states. At the other end of the spectrum are the Scandinavian and Anglo-Saxon countries as well as Hungary. The Eastern European welfare states compensate somewhat for a low overall level of transfer spending with relatively high transfer shares for

10 The spending size for those aged 0-17 portrayed in Figure 4 is visually most informative for showing differences in benefit spending towards children across welfare states. Note that the empirical analysis includes the total spending size and the children's share of spending, in order to separate the impacts of these two components. 
children. The size of pension spending distributed to households with children varies considerably across the sample, as the prevalence of MG households is high in Southern European and Eastern European welfare states and low in Northern European and Western European welfare states. ${ }^{11}$ The cross-sectional correlation between child poverty and the size of spending distributed towards those aged $0-17$ is negative with respect to transfers $(-0.33)$, but strongly positive with respect to pensions $(0.70$; the correlation between pension spending towards the population as a whole and poverty equals 0.47 ). The correlation between the summed level of transfer and pension spending distributed to children and child poverty is a statistically insignificant -0.10 .

Appendix Figure A1 provides trends for all our main explanatory variables. Our pension size indicator steadily increases from 2008 to 2012, mainly through increases in relative spending per pension. Absolute pension spending (not shown) steadily increased across the period 2005-2012, but since all spending is expressed relative to the country mean income in that specific year, the slowdown in mean income growth in the recent recession leads to an especially strong increase after 2008. Spending on other cash transfers increased in response to the recent economic crisis, although additional data shows that there are strong differences across countries in the strength of that response.

\subsection{Pensions in MG households}

Figure 4 combines the CS for pensions with two other series: (i) the share of children living in MG households as a proportion of the total child population (on the horizontal axis); (ii) the ratio of the non-standardized income of MG households relative to the nonstandardized income of other households, reflected by the size of the circles. MG households are defined as households with at least one person under the age of 18, at least one person aged between 18 and 59 and at least one person aged above 59. The income of MG households is lower than the income of other households in all countries, but the precise ratios strongly vary across the EU.

Not surprisingly, there is a very strong positive correlation between the share of children living in MG households and the CS for pensions. Thus, the structure of households is an important driver of the structure of social spending, as we analyse it in this article. Based on Figure 4, we can broadly discern two different clusters of countries in which MG households are a non-negligible reality. ${ }^{12}$ Lithuania, Slovakia, Poland, Latvia, Romania and Bulgaria constitute a first cluster, in which the share of children living in MG households ranges from $4.9 \%$ to more than $15 \%$, while the share of pension spending distributed to children ranges from $23 \%$ (in Lithuania) to $33 \%$ (in Bulgaria). The size of the circles in this cluster indicates that the mean (non-standardized) household income of MG households is lower than the mean income of other households, but not by a large margin; this income ratio ranges from $77 \%$ to $90 \%$. The second cluster encompasses countries of the southern Eurozone (Spain, Italy, Greece, Portugal and Malta) but also countries as diverse as Slovenia, Czech Republic,

11 Note that the children's share is technically not a share, but a ratio that measures spending towards the average child relative to spending towards the average person. It can therefore also exceed 1 .

12 By 'non-negligible' we mean that the share of children living in MG households is larger than 1,5\%. This cutoff point roughly splits the sample in half, and also isolates Southern European and Eastern European welfare states from the rest of the sample. 


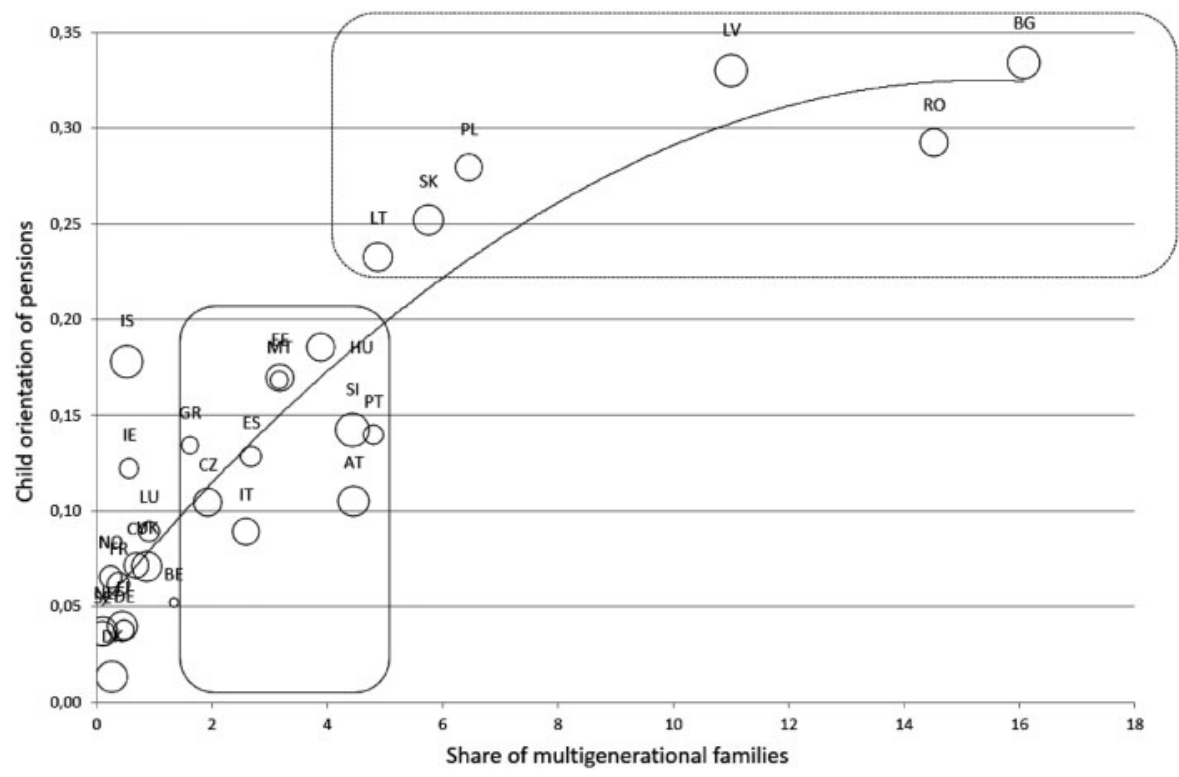

Figure 4. Multigenerational households, pensions and income positions.

Notes: The size of the circles represent the ratio of average income (pre-pension and non-equivalized) of MG households versus average income of other households with children (ratios are reduced with a uniform value of 0.5 to enhance the visual difference).

Source: Own calculations based on EU SILC 2005-2012.

Hungary, Austria and Estonia. The share of children living in MG households is lower than in the first cluster; between $1.6 \%$ and $4.8 \%$. The value of the CS of pensions is between $9 \%$ and $19 \%$. In contrast to Central European and Eastern European countries, MG households in the southern Eurozone countries (except Italy) are substantially poorer than other households with children. Income ratios in these countries range from $62 \%$ to $66 \%$. The southern Eurozone sub-cluster also distributes relatively little non-pension transfers to children (see Figure 3). Hence, pension spending is relatively important to sustain the income of households with children in this sub-cluster. In this regard, the southern Eurozone is similar to countries belonging to the first cluster, like Romania, Bulgaria and Poland, where transfer spending is also on a relatively low level. ${ }^{13}$

If transfer spending is poorly developed and pension spending comparatively important, one may conjecture that there is some degree of endogeneity in the formation of MG households as they constitute a protection against financial poverty. This is supported by regression analysis on the EU SILC micro-level data, which shows that MG households tend to form directly after losses in pre-pension income (not shown but available on request).

13 The comparatively low level of spending on family benefits compared to old age benefits in Southern European welfare states has been well documented in previous research; see e.g. Ferrera (1996). The descriptive statistics presented here show that some Eastern European welfare states are similar in this regard. 
Hence, the considerable diversity in the structure of social spending across the EU reflects differences in socio-demographic structure (with MG households being more common in some countries than in others), but also endogenous processes in which inadequacies in the structure of social spending may be one of the explanatory factors.

\subsection{PP of spending}

Additionally, we include measures of the 'pro-poorness of spending', which captures the distribution of spending by income level. Because the estimated impact of PP may depend on the definition of the variable, we test a range of different measures, including concentration coefficients (following Verbist and Matsaganis, 2013), ratios of transfers or pensions received for specific quantiles of the (post-tax pre-transfer) income distribution and shares of transfers or pensions distributed to the lowest deciles of the income distribution (all measured within the child population). We ultimately select the ratio of transfers distributed to the lowest decile of the income distribution relative to the median of the income distribution and the share of pensions distributed to the lowest half of the income distribution for PP of transfers and PP of pensions, respectively, as these measures provide the strongest explanatory power in our model. Sensitivity to the definition of the PP variable will be discussed in Section 5.3.

\subsection{Taxation}

We also include indicators of the taxation structure of countries. Unfortunately, SILC is not a reliable source for measuring tax liabilities, as the data to distinguish between personal income taxes and social security contributions are missing or incomplete for the majority of countries. Therefore, we rely on data reported by Eurostat and the OECD instead. ${ }^{14}$

As with transfer spending, we distinguish three features: the average tax rate, the degree of progressivity (labelled tax prog) and the ratio of the average tax rates for (families with) children relative to the rest of the population (labelled tax child). ${ }^{15}$ For tax rate, we use the average implicit tax rate on labour (ratio of taxes and social security contributions on employed labour income to total compensation of employees). ${ }^{16}$ For tax prog, we construct ratios of projected tax rates of a single person without children at different income levels, expressed as a percentage of (individual) average earnings, reported by the OECD. The measure we use for tax child is the unweighted average difference in projected tax rates for a two-earner married couple at $100 \%$ and $33 \%$ of average earnings, either with two children or without children. These data are not reported for six non-OECD countries in our sample (Bulgaria, Cyprus, Latvia, Lithuania, Malta and Romania). We test the impact of this variable for the reduced sample.

14 See OECD (2014) for the latest report and an explanation of the methodology.

15 The distinction made here is similar to the analysis in Aronson et al. (1994), which distinguishes between tax rate, progressivity and 'horizontal inequity'; i.e. differentiation in tax treatment for households with similar incomes.

16 The data on the tax rate is retrieved from Eurostat, and uses the methodology discussed in European Union (2014). 


\subsection{Additional data issues}

Explanations on the exact measurement of the control variables in our model are available in Appendix Table A1. As stated before, it is essential that we control for differences in employment. Since we look at household income, not only the individual employment level is relevant but also how this is distributed across households. We include the mean level of household work intensity in our model, as this provides stronger explanatory power than any alternative control for (household) employment. It is measured as the number of months spent working for all working-age individuals in the household divided by the number of months they could have worked, corrected for number of hours worked. We include both a measure of overall household work intensity, as well as a measure of relative household work intensity for households with children versus the population as a whole, in a similar vein as the use of the CS indicators for spending and taxation. CS indicators are also included for education, female labour force participation, self-employment and migration. All these ratios are constructed by dividing the value calculated on households with children by the value calculated on the population as a whole (or the total working population, when we measure labour market characteristics).

In some instances, we do not have information on all control variables for all countryyear observations. In those cases, missing values are imputed based on an estimated trend constructed on the non-missing values. Data are missing for all years with respect to spending on active labour market policies for Iceland and the relative size of industry sectors for Malta. We set the former to 0 and the latter to 1 in all years, but note that the specific level is irrelevant given the fixed effect approach.

\section{Results}

We now present empirical results. We start with a reduced specification of Model 1 that only includes our main measures of the tax-benefit system and add controls for household work intensity and other potential determinants of poverty in later models. We also estimate effects by subsample. In order to disentangle the nature of the impact of each of the design features of the tax-benefit system, we also estimate models that use the relative income of children and 'within poverty' as outcome variables. All results are summarized in Table 1.

\subsection{Spending on cash transfers}

We first estimate the impact of the total size of (other) transfer spending (measured for the population as a whole) and the CS of transfer spending on poverty. The first two rows of Table 1 show these effects, across different model specifications. The results in the full model specification (column (3)) show that increases in spending size and increases in the share of total transfer spending distributed to children both lead to lower poverty. They suggest that an increase in total transfer spending by $1 \%$ of mean equivalized household income would decrease the poverty rate by around 0.3 (holding the CS fixed), while an increase by 1 SD in the CS would decrease the poverty rate by around 0.6 (holding total spending size fixed). When we would express both variables in standard deviations, the impact of size is a factor 2 larger than the impact of CS.

These standardized coefficients are defined by the dispersion in each measure across the sample, which has little intuitive meaning. A more policy-relevant question is how the effect of spending an extra $1 \%$ of mean equivalized household income (labelled $\mathrm{Y}_{\mathrm{i}}$ ) on transfers to 
Table 1. The effect of redistribution on child poverty

\begin{tabular}{|c|c|c|c|c|c|c|c|c|}
\hline & $\begin{array}{l}(1) \\
\text { (AROP) }\end{array}$ & $\begin{array}{l}(2) \\
\text { (AROP) }\end{array}$ & $\begin{array}{l}(3) \\
\text { (AROP) }\end{array}$ & $\begin{array}{l}(4) \\
\text { (AROP) }\end{array}$ & $\begin{array}{l}(5) \\
(\mathrm{WP})\end{array}$ & $\begin{array}{l}(6) \\
(\mathrm{RY})\end{array}$ & $\begin{array}{l}(7) \\
\text { (AROP) }\end{array}$ & $\begin{array}{l}(8) \\
\text { (AROP) }\end{array}$ \\
\hline Transfer size & $\begin{array}{c}-0.195 * * \\
(0.074)\end{array}$ & $\begin{array}{l}-0.303 * * * \\
(0.076)\end{array}$ & $\begin{array}{l}-0.296^{* * *} \\
(0.065)\end{array}$ & $\begin{array}{l}-0.483^{* * * *} \\
(0.087)\end{array}$ & $\begin{array}{c}-0.498^{* * *} \\
(0.069)\end{array}$ & $\begin{array}{c}0.0032 \\
(0.067)\end{array}$ & $\begin{array}{l}-0.482^{* * *} \\
(0.128)\end{array}$ & $\begin{array}{c}-0.222^{*} \\
(0.097)\end{array}$ \\
\hline Transfer CS & $\begin{array}{c}0.416 \\
(0.284)\end{array}$ & $\begin{array}{c}0.069 \\
(0.286)\end{array}$ & $\begin{array}{c}-0.589 * \\
(0.276)\end{array}$ & $\begin{array}{r}-0.713^{\dagger} \\
(0.410)\end{array}$ & $\begin{array}{c}-0.708 * \\
(0.294)\end{array}$ & $\begin{array}{l}1.28^{* * *} \\
(0.275)\end{array}$ & $\begin{array}{r}-1.18^{\dagger} \\
(0.619)\end{array}$ & $\begin{array}{r}-0.725^{\dagger} \\
(0.376)\end{array}$ \\
\hline Transfer PP & $\begin{array}{c}-0.393^{*} \\
(0.155)\end{array}$ & $\begin{array}{c}-0.361 * \\
(0.148)\end{array}$ & $\begin{array}{r}-0.232 \\
(0.146)\end{array}$ & $\begin{array}{r}-0.124 \\
(0.206)\end{array}$ & $\begin{array}{c}-0.391 * \\
(0.155)\end{array}$ & $\begin{array}{c}0.263 \\
(0.167)\end{array}$ & $\begin{array}{c}-0.962 * * \\
(0.362)\end{array}$ & $\begin{array}{r}-0.035 \\
(0.192)\end{array}$ \\
\hline Pension size & $\begin{array}{l}0.265 * * * \\
(0.062)\end{array}$ & $\begin{array}{l}0.191^{* *} \\
(0.059)\end{array}$ & $\begin{array}{l}0.207^{* * *} \\
(0.046)\end{array}$ & $\begin{array}{l}0.299 * * * \\
(0.082)\end{array}$ & $\begin{array}{c}-0.105 * * \\
(0.049)\end{array}$ & $\begin{array}{c}-0.459 * * * \\
(0.050)\end{array}$ & $\begin{array}{l}0.848 * * * \\
(0.147)\end{array}$ & $\begin{array}{c}0.048 \\
(0.049)\end{array}$ \\
\hline Pension CS & $\begin{array}{c}-1.43^{* *} \\
(0.428)\end{array}$ & $\begin{array}{c}-1.34 * * \\
(0.427)\end{array}$ & $\begin{array}{c}-1.04 \% * \\
(0.330)\end{array}$ & $\begin{array}{c}-1.66 * * \\
(0.437)\end{array}$ & $\begin{array}{c}-1.38 * * * \\
(0.374)\end{array}$ & $\begin{array}{c}0.796^{*} \\
(0.342)\end{array}$ & $\begin{array}{r}-0.016 \\
(0.551)\end{array}$ & $\begin{array}{c}-0.957^{*} \\
(0.416)\end{array}$ \\
\hline Pension PP & $\begin{array}{r}-0.056 \\
(0.107)\end{array}$ & $\begin{array}{r}-0.119 \\
(0.101)\end{array}$ & $\begin{array}{r}-0.120 \\
(0.098)\end{array}$ & $\begin{array}{r}-0.168 \\
(0.117)\end{array}$ & $\begin{array}{r}-0.080 \\
(0.124)\end{array}$ & $\begin{array}{r}-0.038 \\
(0.102)\end{array}$ & $\begin{array}{r}-0.164 \\
(0.106)\end{array}$ & $\begin{array}{r}-0.531^{\dagger} \\
(0.286)\end{array}$ \\
\hline Tax rate & $\begin{array}{r}-0.015 \\
(0.069)\end{array}$ & $\begin{array}{c}0.0050 \\
(0.070)\end{array}$ & $\begin{array}{l}-0.272^{* * *} \\
(0.062)\end{array}$ & $\begin{array}{c}-0.185^{*} \\
(0.084)\end{array}$ & $\begin{array}{l}-0.210^{* * *} \\
(0.059)\end{array}$ & $\begin{array}{c}0.108^{\dagger} \\
(0.064)\end{array}$ & $\begin{array}{r}-0.089 \\
(0.141)\end{array}$ & $\begin{array}{c}-0.260 * * \\
(0.074)\end{array}$ \\
\hline Tax prog & $\begin{array}{c}-0.534 * * \\
(0.179)\end{array}$ & $\begin{array}{c}-0.563 * * \\
(0.197)\end{array}$ & $\begin{array}{l}-0.654^{* * *} \\
(0.187)\end{array}$ & $\begin{array}{c}-0.603 * \\
(0.214)\end{array}$ & $\begin{array}{l}-0.808^{* * *} \\
(0.200)\end{array}$ & $\begin{array}{c}0.296^{\dagger} \\
(0.160)\end{array}$ & $\begin{array}{r}-0.155 \\
(0.159)\end{array}$ & $\begin{array}{c}-2.16^{* * *} \\
(0.434)\end{array}$ \\
\hline Tax child & - & - & - & $\begin{array}{c}-0.164^{*} \\
(0.089)\end{array}$ & - & - & - & - \\
\hline $\begin{array}{l}\text { Work } \\
\quad \text { intensity }\end{array}$ & - & $\begin{array}{l}-0.223^{* * *} \\
(0.049)\end{array}$ & $\begin{array}{l}-0.842 * * \\
(0.101)\end{array}$ & $\begin{array}{c}-0.779 * * * \\
(0.128)\end{array}$ & $\begin{array}{c}-0.838^{* * *} \\
(0.104)\end{array}$ & $\begin{array}{c}0.286^{*} \\
(0.135)\end{array}$ & $\begin{array}{r}-0.598 \% \\
(0.243)\end{array}$ & $\begin{array}{c}-0.873^{* * *} \\
(0.121)\end{array}$ \\
\hline \multicolumn{9}{|l|}{ Controls } \\
\hline $\begin{array}{l}\text { Work } \\
\quad \text { intensity }\end{array}$ & & Yes & Yes & Yes & Yes & Yes & Yes & Yes \\
\hline Other & & & Yes & Yes & Yes & Yes & Yes & Yes \\
\hline $\mathrm{N}$ & 219 & 219 & 219 & 179 & 219 & 219 & 101 & 118 \\
\hline
\end{tabular}

Notes: Columns (1)-(4) show estimates with respect to the at-risk-of-poverty rate (AROP) for those aged 0-17, for different model specifications. Column (3) represents Model 1. Columns (5) and (6) estimate Model 1 while using 'within poverty' (WP'; using a poverty threshold based on the child population only) and the 'relative income of children' (RY'; coefficients are multiplied by 100) as outcomes, respectively. Columns (7) and (8) estimate Model 1 for those with average shares of MG households below and above $1.5 \%$, respectively. All models include country and time fixed effects, and use a heteroscedastic error and AR1 autocorrelation structure. Spending size is measured with respect to the population as a whole. See Figure 3 for a definition of children's shares (CS). 'PP transfers' measures the ratio of transfers received by those with 0 pre-transfer income relative to those with median pre-transfer income. 'PP pensions' measures the share of pensions going to the lower half of the pre-transfer income distribution. Tax rate measures the implicit tax rate on labour. Tax progressivity (Tax prog) divides the projected tax rate at $167 \%$ of average earnings by the projected tax rate at $50 \%$ of average earnings (single with no children). Tax child takes the difference in the projected tax rate of a household with two children and a household with no children (both at $133 \%$ of average individual earnings). PP, progressivity and CS measures are standardized with mean 0 and SD 1. 'Other' controls are: GDP, GDP growth, expenditure on R\&D, imports from less developed countries, relative size of industry sectors by skill level, educational attainment, size of vocational education, female labour force participation (LFP), self-employment, investment in active labour market policies, use of child care, young and old age dependency ratios and migration. CS indicators are also included for work intensity, educational attainment, female LFP, self-employment and migration. ${ }^{\dagger} P<0.10, * P<0.05, * P<0.01, * * P<0.001$. 
children compares to the effect of an extra $1 \%$ of $Y_{i}$ on transfer spending to the population as a whole. The latter is given by the coefficient of -0.296 in Table 1 . The former can be identified by directly including a measure of size of transfers sent to children (rather than the CS ratio used in Table 1), while controlling for the size of transfer spending sent to nonchildren. This produces a coefficient of -0.325 . When we estimate the effect of increasing benefits sent to children by $1 \%$ of $Y_{i}$ while holding total cash transfer spending fixed (i.e. the transfers sent to non-children would decrease to hold the total budget constant), the resulting coefficient is -0.414 . Finally, results show that increasing spending to the population as a whole by $1 \%$ of $\mathrm{Y}_{\mathrm{i}}$ while holding the size of transfers distributed to children constant would increase child poverty rates with 0.209 . These results highlight the importance of the relative income of children; both the size and sign of the estimated impact of the same increase in the transfer budget can strongly vary depending on which population group it is targeted to.

The coefficient for transfer size is negative and statistically significant without controlling for work intensity (column (1)), but further increases when these controls are added (column (2)). The estimate for the CS of transfers changes more substantially when we add work intensity controls in column (2) and only becomes statistically significant when we add the full set of controls in column (3). The change in the coefficient can almost completely be attributed to including the control for female labour participation. Table 1 also reports the coefficient for work intensity across specifications. The main model (column 3) suggests that an increase in average household work intensity (defined from 0 to100) by 1 would decrease child poverty by 0.842 . This suggests that transfers would need to increase by around $2.8 \%$ of $\mathrm{Y}_{\mathrm{i}}$ to compensate for a reduction in work intensity by 1 percentage point.

\subsection{Spending on pensions}

Relative income becomes even more important when we look at the role of pensions. Two opposite mechanisms are identified. Increases in total pension spending increase child poverty, while higher CS decrease child poverty. The key distinction with the result for cash transfers is that pensions are predominantly distributed to households without children, thereby increasing the poverty threshold more than the income for children. At the current level of CS, higher pension benefits increase child poverty. The estimate for the CS of pensions indicates that pension benefits that end up in households with children have the potential to lift those households out of poverty. More specifically, the coefficient suggests that around 135000 more children under the age of 18 in the EU27 plus Iceland and Norway would live in poverty in the absence of any pension income distributed to households with children (i.e. the CS indicator would be 0). Alternatively, a doubling of the current share of pensions distributed to children (which is equivalent to a $1.46 \mathrm{SD}$ increase) would reduce the child poverty rate by 1.5 . At the same time, increases in overall pension spending by $1 \%$ of $\mathrm{Y}_{\mathrm{i}}$ increase poverty rates by 0.207 . The estimates for pension spending are stable across columns (1)-(3). ${ }^{17}$

17 Conversely, one can estimate how pension spending size would affect poverty among the elderly. Results indicate that reducing pension size by $1 \%$ of $Y_{i}$ would increase elderly poverty by 0.616 . Exploring the importance of pensions and relative income aspects for elderly poverty in more detail provides an interesting avenue for future research. 
Pension spending size captures both the size of the average pension ('generosity') and the number of pensions distributed. One would expect that the generosity of pensions would drive the relative income effect and therefore the positive impact of size on poverty. The impact of the number of pensions on relative income depends on the incomes that extra-pensioners 'replace' (i.e. market income and/or other cash transfers). When we split up the effect of pension size into these two components, the coefficient for the number of pensions is negative but marginally statistically significant and low in magnitude, while the effect for pension generosity (corrected for changes in mean income) is positive. It suggests that an increase in generosity by $10 \%$ per individual pension would increase child poverty by 0.436 .

Pension benefits as we measure them consist of both old age benefits and survivor benefits. We estimate effects for each type separately as well. For both types, we find a positive and statistically significant effect for size and a negative and statistically significant effect for CS. The point estimates are higher for survivor benefits when we look at size and higher for old age benefits when we look at CS. However, these differences are not statistically significant, partly because the estimates for survivor benefits are relatively imprecise.

\subsection{PP and taxation}

The third and sixth row of Table 1 show that the PP of both transfer spending and pension spending are negatively related to poverty. However, this effect is relatively small in magnitude and not consistently statistically significant across specifications. All results are standardized; they imply that an increase in PP by 1 SD reduces the poverty rate by around 0.232 for transfers and 0.120 for pensions. The coefficient for PP of transfers is just shy of being statistically significant in column $(3)(P=0.11) .^{18}$

We further find that a higher (implicit) tax rate on labour, and increased tax progressivity (tax prog) both reduce poverty. The coefficient on progressivity shows the effect of an increase by $1 \mathrm{SD}$. If we step away from using progressivity ratios but directly include tax rates at different income levels, the results (not shown) suggest that poverty rates reduce by around 0.150 when the tax rate for those at $50 \%$ of average income decreases by 1 percentage point. Tax rates at any higher level of average income (including 67\%) are negatively related to poverty, with coefficients centring just below -0.200 (which is close to the coefficient for the average implicit tax rate). Table A3 shows the impact of tax progressivity on child poverty under different progressivity ratios. It indicates that the degree of progressivity relative to the low end of the earnings distribution (i.e. the $50 \%$ group) is what matters most. Finally, column (4) indicates that relatively lower taxation to households with children is related to lower child poverty. Increasing the difference in the tax rate between the two groups by 1 percentage point leads to a reduction in poverty by -0.185 , which is slightly above the effect of lowering the tax rate for low earners (but is likely to involve much higher public costs). ${ }^{19}$

18 The top panel of Appendix Table A3 shows that the estimated impact of PP is similar under different definitions of PP. Variables that measure PP relative to the lowest decile exhibit slightly larger point estimates.

19 The decrease in the coefficient for the tax rate in column (4) can be completely attributed to the change in the sample composition; estimating the model from column (3) on the reduced sample shows an identical decrease. The same applies to the change in the transfer spending coefficients in column (4). 


\subsection{Relative income and 'within poverty'}

As specified in Section 2, at-risk-of-poverty rates for children are shaped by both the distribution of household income within the group of children and the relative income position of children versus the rest of the population. Columns (5) and (6) of Table 1 show results for Model 1 when we use the previously defined 'within poverty' and 'relative income of children' variables as outcomes. These results show that the manner in which the design features of social spending affect child poverty differs by 'component' of child poverty. The effect of pension size operates exclusively through the relative income position of children. The effect of pension CS operates through both mechanisms. More pensions to children improve relative income, and they reduce poverty within the child population, since they are predominantly distributed to poor children. In fact, column (5) shows that all of the distinguished aspects of redistribution are negatively related to 'within poverty'. For relative income, the coefficient for transfer size is positive but statistically insignificant. Average transfer spending is higher for households with children compared to all other households, but not by a very wide margin, which explains the positive but low estimate. Increased CS of transfers, on the other hand, have a very substantial positive effect on the relative income of children. $^{20}$

\subsection{Low MG versus high MG countries}

Section 5.1 shows that pensions have two partially offsetting impacts on child poverty. The relative importance of each of these effects logically depends on the prevalence of MG households in the country. Columns (7) and (8) show results when we split up the sample into countries with low prevalence of MG households and countries with high prevalence of MG household (i.e. with average rates of MG households smaller or larger than $1.5 \%$ of all households with children). The results show that the positive effect of pension size is much stronger for the former group, as there are virtually no MG households to compensate for the declining relative income position of children. For countries with high MG, the size effect is essentially zero, as the two forces offset each other. Note that pensions are still distributed predominantly to households without children in these countries, but the fact that MG households are generally poor drives the net effect to near zero. Another interesting observation from these results is that all three aspects of transfers are less effective in high MG countries. This is consistent with our conjecture that a lack of adequate support from transfers that are aimed at children is an important driver behind the formation of MG households; transfer spending is not only lower in these countries, it also appears less effective given its size.

The results from column (7) and (8) suggest that inter-household transfers are unlikely to affect our results. If inter-household transfers would be an important side effect through which pensions could contribute to the income of households with children, one would expect that the impacts of pensions on child poverty would be relatively more favourable in Northern and Western European countries, where inter-household transfers are found to be relatively higher, compared to Southern and Eastern European countries. We find the opposite, which is indicative evidence that the other defined mechanisms (the direct weakening of

20 As an alternative to relative income, we have also used the relative poverty risk of children as an outcome (dividing the child poverty rate by the poverty rate for the total population). Results for this outcome are very similar to those for relative income and available on request. 
relative income position and the presence of MG households) are the main drivers of our results. Naturally, inter-household transfers remain an important dimension of intergenerational solidarity. Only, in the context of pensions and child poverty, their empirical relevance seems relatively limited. ${ }^{21}$ This might be driven by the fact that such transfers are typically made before pension age and between households that are typically not close to the poverty margin (see e.g. Schenk et al., 2010).

\subsection{Explanatory power}

We further assess how much these indicators explain of the total variation in poverty rates in the period covered by SILC 2005-2012. As the GLS model does not allow for calculation of a traditional $R^{2}$, we rely on the within- $R^{2}$ of an equivalent ordinary least squares fixed effect model here. ${ }^{22}$ The complete Model (1) explains 53\% of the within-country variation in poverty, of which $6 \%$ can be attributed to the three elements of transfer spending, $5 \%$ to pension spending, $4 \%$ to taxation and $12 \%$ to the level of household work intensity. ${ }^{23}$ Hence, the global impact of the tax-benefit system has been most important (15\%), but at a disaggregate level the impact of household work intensity is largest. Nonetheless, the explanatory power of spending size and CS is sizable, and significantly exceeds that of PP.

Our results suggest that the increase in poverty over the period covered by SILC 20082011 would be higher by about one-third $(+1.85$ rather than the observed +1.42$)$ in the absence of an increase in transfer spending over that period. These average effects across the sample hide a fair share of heterogeneity within. For example, the surge in transfer spending in Ireland and Lithuania during the crisis is associated with a 2.9 and 3.1 decrease in poverty rates, respectively. For the sample as a whole, increases in pension spending during the crisis (relative to mean income) have exactly neutralized the positive average effects of increased transfer spending. ${ }^{24}$ Hence, changes in pension spending have been just as important for mean trends in child poverty as the considerable surge in transfer spending has been. The recent positive trend in pension spending could have substantial adverse consequences for child poverty in the years to come if it would persist. The other main measures of redistribution do not contribute much to poverty trends during the crisis, either because effects sizes are limited (PP) or because measures are relatively stable over time (taxation).

\subsection{Robustness}

We have performed multiple tests and analyses to assess the robustness of the main findings. We have assessed sensitivity to different econometric models, error specifications, sample compositions and equivalence scales. Results from these robustness checks are available in Appendix Tables A4 and A5. The tables show that the main results are very similar under these alternative specifications. Additionally, Appendix Table A6 reports results for

21 This is under the assumption that such transfers are sufficiently incorporated in the household income measures.

22 This model provides very similar coefficients for the main explanatory variables; see Appendix Table A4.

23 This is based on an exercise in which we drop each set of variables from the complete model and take the difference between the within- $R^{2}$ from the complete model and each reduced model.

24 See Appendix Figure A2 for trends in spending generosity and the share of the population receiving pension benefits. The figure shows a marked increase in generosity since the crisis, both for countries with high and low pension spending. 
alternative poverty thresholds. At a threshold of $50 \%$ of median equivalized household income, results are highly comparable to those in the main approach; the poverty-reducing impact increases slightly for most of the main explanatory variables, while the adverse impact of pension size is somewhat lower. Coefficients reduce somewhat when we use a $40 \%$ threshold. This likely occurs because such severe poverty is relatively rare in this sample, and therefore precisely eliciting impacts becomes more difficult.

As indicated in Section 2.1, the analysis assumes that all resources are shared within the household. As such, the impact of the CS of pensions likely measures an upper bound; it represents the impact of pensions in MG households on poverty given that pension benefits are fully shared within the household. The opposite applies to the impact of pension size, which likely represents a lower bound. Table 2 shows the effects of social spending measures on poverty under alternative assumptions about resource sharing. Under these alternatives, we exclude a certain percentage of pension benefits from the measure of pension benefits distributed to children, which leads to both a lower CS of pensions and a lower total household income for children. The impact of the CS in Table 2 naturally decreases to zero if we move towards a $0 \%$ sharing assumption. At the same time, the impact of the size of pension spending increases, as the ratio becomes less favourable for children. In the most extreme case the impact is 0.371 . Even though the exact coefficients are sensitive to assumptions about resource sharing, the contrasting result between pension size and CS of pension spending remains, assuming at least some resources are shared. The exact level of resource sharing simply determines the relative sizes of each effect.

SILC 2010 provides concrete evidence on how resources are shared within households. The data indicate that MG households are less likely to completely treat all income as common resources (48\% for MG households versus $70 \%$ for non-MG households). However, the share of households that treats all income as private is similarly low ( $8 \%$ versus $7 \%)$. In other words, MG households are more likely to share part of their income rather than all of it. When we look at the individual level, we find that the elderly in MG households are rather eager to share their income; $46 \%$ indicates that no income is kept separate from the common household budget, while a cumulative $76 \%$ indicates that less than half is kept separate (less than $9 \%$ keeps all income separate). The degree of sharing is even slightly higher for elderly in MG households with household income under the poverty threshold (before transfers). Hence, although the assumption that all income is shared is in all likelihood too strong, there is strong evidence that at least a very substantial share of pension benefits of elderly in MG households is shared. ${ }^{25}$

\section{Conclusion}

This study assesses the impact of redistribution on child poverty across European welfare states, with an explicit focus on the role of pension spending versus spending on all other cash transfers. For both (other) transfers and taxation, we find that size, PP and child orientation are all negatively related to poverty. For pensions, there are two opposing forces. Increases in overall pension spending lead to higher child poverty because they are predominantly

25 The individual-level data on income sharing of the elderly in MG households suggests an average sharing rate close to $75 \%$. As can be seen in Table 2, the results are very similar under this assumed level of sharing. 
Table 2. Redistribution effects under different levels of resource sharing

\begin{tabular}{lcccccc}
\hline & Transfer size & Transfer CS & Transfer PP & Pension size & Pension CS & Pension PP \\
\hline Baseline $(100 \%)$ & $-0.296 * * *$ & $-0.589 *$ & -0.232 & $0.207 * * *$ & $-1.04 * *$ & -0.120 \\
& $(0.065)$ & $(0.276)$ & $(0.146)$ & $(0.046)$ & $(0.330)$ & $(0.098)$ \\
$75 \%$ sharing & $-0.293 * * *$ & $-0.560 *$ & -0.160 & $0.253 * *$ & $-0.734 *$ & -0.085 \\
& $(0.065)$ & $(0.284)$ & $(0.146)$ & $(0.048)$ & $(0.322)$ & $(0.093)$ \\
$50 \%$ sharing & $-0.307 * *$ & -0.399 & -0.137 & $0.292 * * *$ & -0.476 & -0.016 \\
& $(0.065)$ & $(0.293)$ & $(0.137)$ & $(0.043)$ & $(0.297)$ & $(0.082)$ \\
$25 \%$ sharing & $-0.302 * * *$ & $-0.479 \dagger$ & -0.092 & $0.357 * *$ & -0.121 & -0.059 \\
& $(0.064)$ & $(0.287)$ & $(0.129)$ & $(0.041)$ & $(0.292)$ & $(0.078)$ \\
No sharing & $-0.296 * *$ & $-0.566 *$ & -0.047 & $0.371 * * *$ & - & -0.060 \\
& $(0.062)$ & $(0.276)$ & $(0.127)$ & $(0.036)$ & & $(0.073)$ \\
\hline
\end{tabular}

Notes: The table shows the effects of transfer and pension total size, child share (CS) and pro-poorness (PP) of social spending on child poverty under different assumptions of resource-sharing with respect to pension benefits. For example, ' $75 \%$ sharing' means that only $75 \%$ of the pension benefits in the household are included in the household income of the child.

${ }^{\dagger} P<0.10, * P<0.05, * * P<0.01, * * P<0.001$.

distributed to households without children, while an increase in the share of pension benefits that ends up in (multigenerational) households with children reduces poverty. The results reflect that aspects of redistribution that affect the relative income position of children can be crucial when explaining measures of (relative) poverty that are typically used in both the academic and political debate, since such measures instantiate both inequality within the child group as well as the relative income position of households with children.

Although overall increases in pension benefits are related to higher poverty, a substantial share of households with children in Southern and Eastern European welfare states rely on such benefits. As such, these pension benefits have the potential to lift such households out of poverty. This ambiguous finding implies that the impact of pensions on children's welfare crucially depends on the measure of poverty or inequality one is interested in. If we are interested in poverty rates relative to a national time-varying threshold, pensions are-on average-clearly harmful for child poverty, holding all other characteristics constant. However, if we are interested in reducing inequality within the child population or reducing the share of children living under a certain absolute income level, pension benefits are actually beneficial as they are highly pro-poor within the population of children.

Our analysis measures the short-term impact of pension benefits, holding constant other factors such as transfer spending, taxation and employment. Effects that operate through other independent variables or effects that only operate in the long run are not reflected in the estimates. The fact that we identify a strong and positive cross-sectional correlation between child poverty and the level of pension spending, both when measured within the child population and when measured within the total population, might suggest that the 'pensionheaviness' of these welfare states has a structural crowding-out effect on spending and investments in alternative policies, which might be more effective in addressing poverty. Such crowding-out effects could impact transfer spending and active labour market policies, but potentially also policies whose benefits might only be reaped in the longer run, such as investments in education and child care. Pension-heavy welfare states that are making 
necessary changes to the structure of their spending need to be aware that this restructuring increases the poverty risk of households with children that rely on pension income, in addition to the general concern of ensuring a sufficient income for the elderly. To prevent this, pension reform in these countries (of which Greece is the most telling example) needs to be accompanied by the development of more adequate transfer systems for working-age households, notably households with children.

On a more general note, our results for sub-samples underscore that 'one-size-fits all' is not a good approach to EU social policymaking. The importance of national circumstances in relation to poverty has been emphasized by recent scholars, but typically in the context of differences in 'acceptable' standards of living; see e.g. Deeming (2015). Additionally, 'onesize-fits-all' is shown to be misguided when it comes to the relations between policy inputs and policy outcomes. Earlier comparative research on family support policies, based on microsimulation, has shown that not only the level of spending and its structure, but also the way in which both interact with the national context are important determinants of child poverty (Levy et al., 2007). Policy packages that are successful in country A with regard to child poverty are not necessarily as successful in country B, even if those countries appear relatively similar in overall welfare state architecture: policies in country A may be better aligned to its own socio-demographic settings than is the case in country B (see Salanauskaite and Verbist (2013, p. 328), with reference to Lithuania and Estonia). These simulations focus on family support systems in a narrow sense; our article enhances this insight by zooming in on the role of social programmes that are not traditionally seen as part of family support systems, such as pensions, and how they interact with country-specific demographic conditions. While the EU should define ambitious and stringent goals with respect to social outcomes, such as the reduction of child poverty, its guidelines and recommendations should leave sufficient room of manoeuvre for Member States with respect to the ways and means to achieve these outcomes. Benchmarking of policies should be based on 'policy packages', rather than on single policy instruments (see Cantillon et al. (2015) for an illustration of benchmarking on the basis of 'policy packages'). This is a fortiori true when they have to introduce large-scale reform in existing social programmes. Countryspecific recommendations, issued by the European institutions in the context of the so-called European Semester, must take that precaution on board.

\section{Acknowledgements}

We would like to thank Bruno Amable, Brian Burgoon, Vincent Corluy, Tim Goedemé, Geranda Notten, Joakim Palme, Pierre Pestieau, Andre Sapir, Erik Schokkaert, Olaf van Vliet, Chen Wang, the participants of the 2014 ImPRovE Mid-term Conference in Antwerp and three very knowledgeable referees for their valuable comments.

\section{References}

Adamson, P. (2012) Measuring Child Poverty: New League Tables of Child Poverty in the World's Rich Countries. Technical Report inreca660, UNICEF Innocenti Research Centre, Florence.

Albertini, M. and Kohli, M. (2012) 'The Generational Conflict in the Family: An Analysis of Transfer Regimes in Europe', European Sociological Review, 17, 1-13. 
Albertini, M., Kohli, M. and Vogel, C. (2007) 'Intergenerational Transfers of Time and Money in European Families: Common Patterns-Different Regimes?' Journal of European Social Policy, 17, 319-334.

Aronson, J. R., Johnson, P. and Lambert, P. J. (1994) 'Redistributive Effect and Unequal Income Tax Treatment', The Economic Journal, 104, 262-270.

Baltagi, B. H. (1995) Econometric Analysis of Panel Data, New York, Wiley.

Beck, N. and Katz, J. D. (2011) 'Modeling Dynamics in Time-Series-Cross-Section Political Economy Data', Annual Review of Political Sciences, 14, 331-352.

Bradley, D., Huber, E., Moller, S., Nielsen, F. and Stephens, J. D. (2003) 'Distribution and Redistribution in Postindustrial Democracies', World Politics, 55, 193-228.

Bradshaw, J. and Holmes, J. (2013) 'An Analysis of Equity in Redistribution to the Retired and Children over Recent Decades in the OECD and UK', Journal of Social Policy, 42, 39-56.

Bronchetti, E. and Sullivan, D. (2004) 'Income packages of households with children: a crossnational correlation analysis', Socio-Economic Review, 2, 315-339.

Cantillon, B., Marchal, S. and Luigjes, C. (2015) 'Decent Incomes for the Poor: Which Role for Europe?, Improve Discussion Paper 15/20. Antwerp, Herman Deleeck Centre for Social Policy, University of Antwerp.

Chen, W. H. and Corak, M. (2008) 'Child Poverty and Changes in Child Poverty', Demography, $45,537-553$.

Cooper, K. and Stewart, K. (2013) Does Money Affect Children's Outcomes? A Systematic Review. York, UK, Joseph Rowntree Foundation.

Deeming, C. (2015) Defining Minimum Income (and Living Standards) in Europe: Methodological Issues and Policy Debate, Social Policy and Society, FirstView Article: DOI: 10.1017/S147474641500041X.

Duflo, E. (2000) 'Child Health and Household Resources in South Africa', American Economic Review, 90, 393-398.

Duncan, G. J., Morris, P. A. and Rodrigues, C. (2011) 'Does Money Really Matter? Estimating Impacts of Family Income on Young Children's Achievement with Data from Randomassignment Experiments', Developmental Psychology, 47, 1263.

Esping-Andersen, G. and Sarasa, S. (2002) 'The Generational Conflict Reconsidered', Journal of European Social Policy, 12, 5-21.

European Union (2014) Taxation Trends in the European Union: Data for the EU Member States, Iceland and Norway. Technical Report, Brussels, Belgium.

Ferrera, M. (1996) 'The "Southern Model" of Welfare in Social Europe', Journal of European Social Policy, 6, 17-37.

Förster, M. F. and Tóth, I. G. (2001) 'Child Poverty and Family Transfers in the Czech Republic, Hungary and Poland', Journal of European Social Policy, 11, 324-341.

Fortin, B. and Lacroix, G. (1997) 'A Test of the Unitary and Collective Models of Household Labour Supply', The Economic Journal, 107, 933-955.

Greene, W. H. (2003) Econometric Analysis, 5th edn, Upper Saddle River, NJ, Prentice Hall.

Hamoudi, A. and Thomas D. (2005) Pension Income and the Well-being of Children and Grandchildren: New Evidence from South Africa. California Center for Population Research 043-05.

Heckman, J. J. (2000) 'Policies to Foster Human Capital', Research in Economics, 54, 3-56.

Heuveline, P. and Weinshenker, M. (2008) 'The International Child Poverty Gap: Does Demography Matter?', Demography, 45, 173-191.

Kenworthy, L. (2011) Progress for the Poor, Oxford, UK, Oxford University Press.

Kittel, B. and Winner, H. (2005) 'How Reliable is Pooled Analysis in Political Economy? The Globalization-Welfare State Nexus Revisited', European Journal of Political Research, 44, 269-293. 
Korpi, W. and Palme J. (1998) 'The Paradox of Redistribution and Strategies of Equality: Welfare State Institutions, Inequality and Poverty in the Western Countries', American Sociological Review, 63, 661-687.

Levin, A., Lin, C. -F. and Chu, C. -S. J. (2002) 'Unit Root Tests in Panel Data: Asymptotic and Finite-sample Properties', Journal of Econometrics, 108, 1-24.

Levy, H., Lietz, C. and Sutherland, H. (2007) 'Swapping Policies: Alternative Tax-benefit Strategies to Support Children in Austria, Spain and the UK', Journal of Social Policy, 36, 625-647.

Maddala, G. and Wu, S. (1999) 'A Comparative Study of Unit Root Tests with Panel Data and a New Simple Test', Oxford Bulletin of Economics and Statistics, 61, 631-652.

Marx, I., Salanauskaite, L. and Verbist, G. (2013) The Paradox of Redistribution Revisited: And that it May Rest in Peace? IZA Discussion Papers 7414. Bonn, Germany, Institute for the Study of Labor.

Matsaganis, M., O’Donoghue, C., Levy, H., Coromaldi, M., Mercader-Prats, M., Farinha Rodrigues, C., Toso, S., and Tsakloglou, P. (2007) 'Child Poverty and Family Transfers in Southern Europe'. In Spadaro A. (ed.) Microsimulation as a Tool for the Evaluation of Public Policies: Methods and Applications, Volume 3 of Handbooks in Economics, Chapter 8, Bilbao, Fundacion BBVA, pp. 293-321.

Moller, S., Bradley, D., Huber, E., Nielsen, F., and Stephens, J. D. (2003) 'Determinants of Relative Poverty in Advanced Capitalist Democracies', American Sociological Review, 68, 22-51.

Notten, G. and Gassman, F. (2008) 'Size Matters: Targeting Efficiency and Poverty Reduction Effects of Means-tested and Universal Child Benefits in Russia', Journal of European Social Policy, 18, 260-274.

OECD (2011) Divided We Stand: Why Inequality Keeps Rising, Paris, France, OECD Publishing.

OECD (2014) Taxing Wages 2014, Paris, France: OECD Publishing.

Pesaran, M. H. (2004) General Diagnostic Tests for Cross Section Dependence in Panels, Cambridge Working Papers in Economics, No. 0435, Cambridge, UK, University of Cambridge.

Salanauskaite, L. and Verbist, G. (2013) 'Is the Neighbour's Grass Greener? Comparing Family Support in Lithuania and Four Other New Member States', Journal of European Social Policy, 23, 315-331.

Schenk, N., Dykstra, P. and Maas, I. (2010) 'The Role of European Welfare States in Intergenerational Money Transfers: A Micro-level Perspective', Ageing and Society, 30, $1315-1342$.

Schultz, T. P. (1990) 'Testing the Neoclassical Model of Family Labor Supply and Fertility', Journal of Human Resources, 25, 599-634.

Smeeding, T. M. (2005) 'Public Policy, Income Inequality, and Poverty: The United States in Comparative Perspective', Social Science Quarterly, 86, 955-983.

Tepe, M. and Vanhuysse, P. (2010) 'Elderly Bias, New Social Risks and Social Spending: Change and Timing in Eight Programmes across Four Worlds of Welfare, 1980-2003', Journal of European Social Policy, 20, 217-234.

Thomas, D. (1990) 'Intra-household Resource Allocation: An Inferential Approach', Journal of Human Resources, 25, 635-664.

Verbist, G. and Matsaganis, M. (2013) 'The Redistributive Capacity of Services in the European Union'. In Cantillon, B. and Vandenbroucke, F. (eds) Reconciling Work and Poverty Reduction, Chapter 6. New York, US, Oxford University Press, pp. 185-211. 


\section{Appendix}
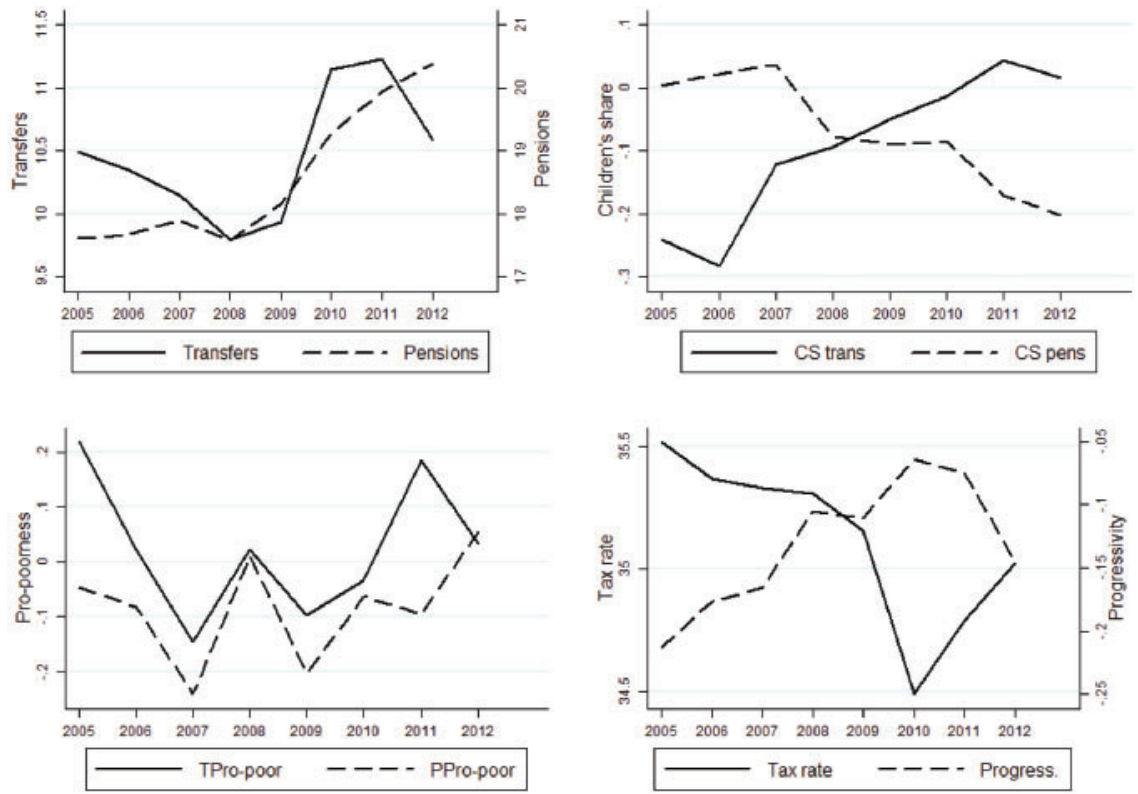

Figure A1. Trends in redistribution.

Notes: The figure shows the mean levels of all main explanatory variables, across SILC cohorts. We only include countries that are present in SILC in all waves, which excludes Belgium, Bulgaria, Ireland, Malta, Romania and the UK. 'CS trans' and 'CS pens' refer to the age differentiation indexes for transfers and pensions, respectively. 'TPro-poor' and 'PPro-poor' refer to PP of transfer and pensions, respectively. For a description of all variables, see Table 1 of the main article. All social spending data are based on EU SILC 2005-2012. Tax data are retrieved from Eurostat.

Source: Own calculations based on EU SILC 2005-2012. 

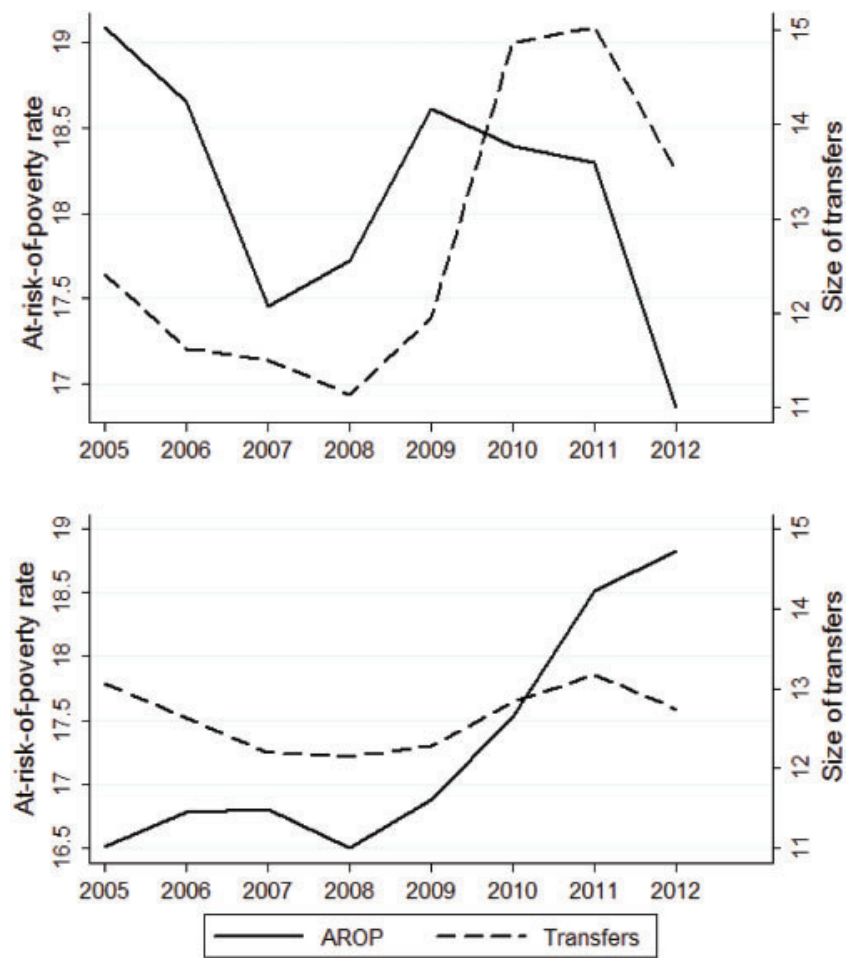

Figure A2. Trends in poverty and the size of transfer spending.

Notes: The figure shows trends in the at-risk-of-poverty rate (AROP; based on a threshold of $60 \%$ of median equivalized household income) and in the size of transfer spending (distributed to those aged 0-17) for SILC 2005-2012. The top panel shows trends for those countries with a decrease in the poverty rate between 2008 and 2012, while the bottom panel shows trends for countries with an increase in the poverty rate from 2008 to 2012. All data are based on EU SILC 2005-2012.

Source: Own calculations based on EU SILC 2005-2012. 


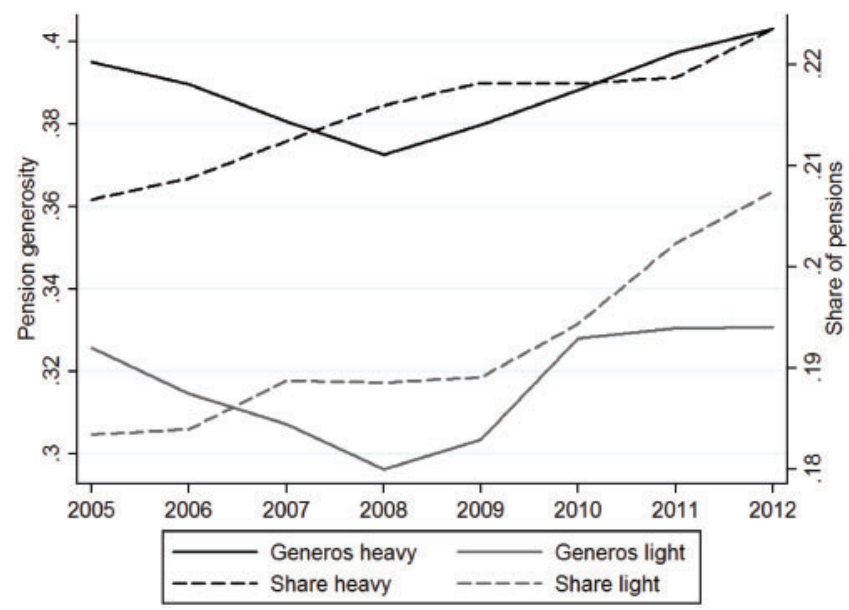

Figure A3. Pension generosity and share of population with pension over time.

Notes: The figure shows the generosity of the average individual (public) pension as a share of mean (unequivalized) household income for country $\mathrm{C}$ in year $\mathrm{T}$ (calculated on all individuals with positive pension benefits) and the share of individuals in the population with positive pension benefits, separately for countries that are 'pension-heavy' in terms of social spending and all other countries (labelled as 'pension-light'). Pension-heaviness is attached to those countries where the pension spending towards the average individual in that country is above the average of the total sample.

Source: Own calculations based on EU SILC 2005-2012. 
Table A1. Description and measurement of control variables

Household work intensity: Individual work intensity is based on the number of months spent working, corrected for number of hours worked. It excludes full-time students between age 18 and 24 . This is summed up for all working age adults (aged 18-59) in the household and divided by the total number of working age adults in the household. This value is then averaged across the population. Source: SILC microdata (refers to own calculations based on SILC microdata throughout this table)

GDP/capita: Gross domestic product per capita in purchasing power parity. Source: Eurostat

GDP growth: Percentage change in GDP from previous year. Source: Eurostat

Sector structure: Share of employment in the high-skilled sector (legislators, managers, professionals, technicians and associate professionals) divided by the share of employment in the medium-skilled sector (craft and related trade workers, plant and machine operators and assemblers, skilled agricultural and fishery workers, service workers, shop and market sales workers, clerks). Source: SILC microdata

R\&D expenditures: Gross domestic expenditure on research and development, as a percentage of GDP. R\&D comprise creative work undertaken on a systematic basis in order to increase the stock of knowledge, including knowledge of man, culture and society and the use of this stock of knowledge to devise new applications. Source: Eurostat

Imports from less-developed countries: Value (at market prices) of imports from low and middle income countries, as a percentage of GDP. Low- and middle-income countries are those with per capita gross national income below US\$12.275 in 2010 (which includes China). Source: own calculations based on Eurostat

Education: Ratio of share of people with high educational attainment (ISCED level 5-6) to share of people with low educational attainment (ISCED 0-2). We include both a measure calculated on the population as a whole and a ratio taking the value for families with children under the age of 18 relative to the value for the population as a whole. Source: SILC microdata

Vocational education: Share of pupils in upper secondary education enrolled in a vocational stream. Source: Eurostat

ALMP: Public expenditure on active labour market policy, measured as a percentage of GDP. Includes training, employment incentives, supported employment and rehabilitation, job creation and startup incentives. Source: Directorate-General for Employment, Social Affairs and Equal Opportunities (via Eurostat)

Use of child care: Average number of hours spent in center-based child care services for those aged under the age of 13. Source: SILC microdata

Self-employment: Share of those in employment that report being self-employed. We include both a measure calculated on the population as a whole and a ratio taking the value for families with children under the age of 18 relative to the value for the working population as a whole. Source: SILC microdata

Female labour force participation: Average work intensity of women. Work intensity is defined as described above. We include both a measure calculated on the total female population and a ratio taking the value for mothers of children under the age of 18 relative to the value for all working age women. Source: SILC microdata

Migration: Share of households with at least one member born not in the reporting nation and not in another EU country. We include both a measure calculated on the population as a whole and a ratio taking the value for families with children under the age of 18 relative to the value for the population as a whole. Source: SILC microdata

Young age dependency: Ratio of population aged 0-14 to population aged 15-64. Source: Eurostat Old age dependency: Ratio of population aged 65 and older to population aged 15-64. Source: Eurostat

Notes: The table describes all variables that are included in the main estimation model in addition to the main measures related to social spending and taxation. 
Table A2. Panel data test statistics

\begin{tabular}{lcr}
\hline & $\chi^{2}$ & $P$-value \\
\hline F country & 1562.14 & 0.000 \\
F time & 49.74 & 0.000 \\
Heteroscedasticity & 529.63 & 0.000 \\
Autocorrelation & 26.18 & 0.000 \\
CSD & 1.408 & 0.159 \\
& Stat & $P$-value \\
LLC & -5.7992 & 0.000 \\
LLC, trend & -6.1479 & 0.000 \\
LLC, demean & -10.9243 & 0.000 \\
LLC, demean trend & -14.9045 & 0.000
\end{tabular}

Notes: The table reports test statistics and $P$-values for: an $F$-test for country and time fixed effects, a modified Wald test for groupwise heteroscedasticity (Greene, 2003), an LM test for AR1 autocorrelation (Baltagi, 1995, p. 95), and a Pesaran test for cross-sectional dependence (CSD) (Pesaran, 2004). In the lower part of the table, we test for non-stationarity based on Levin et al. (2002). $\mathrm{H}_{0}=$ non-stationarity. The test-statistic (stat) reports the adjusted t statistic. All tests are conducted on the model from column (5) of Table 1 in the main article.

Table A3. The effect of PP and progressivity on child poverty under different measures

Panel A: PP of spending

$\begin{array}{lllll}\text { CC CC low Share } 0-20 & \text { Share } 0-50 \quad 90 / 0 & 50 / 0 & 50 / 25 & 25 / 0\end{array}$

$\begin{array}{lllllllll}\text { Transfers } & 0.177 & -0.180 & -0.148 & -0.122 & -0.189 & -0.232 & -0.031 & -0.136\end{array}$

$\begin{array}{llllllll}(0.263) & (0.316) & (0.227) & (0.237) & (0.177) & (0.146) & (0.085) & (0.141)\end{array}$

Pensions $\quad-0.073 \quad-0.295 \quad-0.136 \quad-0.119 \quad 0.122 \quad-0.120 \quad-0.114 \quad-0.118$

$\left.\begin{array}{llllllll}(0.106) & (0.158) & (0.104) & (0.102) & (0.100) & (0.098) & (0.100) & (0.099\end{array}\right)$

Panel B: tax progressivity

$\begin{array}{ccccccc} & 167 / 50 & 125 / 50 & 100 / 50 & 125 / 67 & 100 / 67 & 167 / 100 \\ \text { Tax prog } & -0.656 * * * & -0.650 * * * & -0.664 * * * & -0.086 & 0.0079 & -0.383 \\ & (0.187) & (0.188) & (0.192) & (0.196) & (0.153) & (0.303)\end{array}$

Notes: The table shows the effects of PP of transfers and pensions and progressivity of taxes on child poverty (based on a threshold of $60 \%$ of median equivalized household income), under different definitions of the explanatory variables. All models further include all variables from the model in column (5) of Table 1 of the main table. All variables are standardized with mean 0 and SD 1, and are converted when necessary to reflect that higher values represent higher PP or progressivity. The first entry has concentration coefficients (CC) for both variables. 'CC half' uses CC's calculated on the bottom half of the distribution. 'Share 0-20' measures the share of benefits received by the lowest two deciles; 'share 0-50' measures the share received by the lowest five deciles. All other entries for panel A use ratios of benefits received for specific percentiles in the (pre-transfer) income distribution (where 0 refers to those with 0 pre-transfer earnings). For pensions, we use 'share 0-50' in all of the last four entries, as pension spending is too low to reliably establish percentile ratios in some countries. Panel B reports tax progressivity for ratios using different levels of average earnings (all for a single person with no children). Taxes include income taxes and employees' social security contributions.

$* * P<0.001$. 


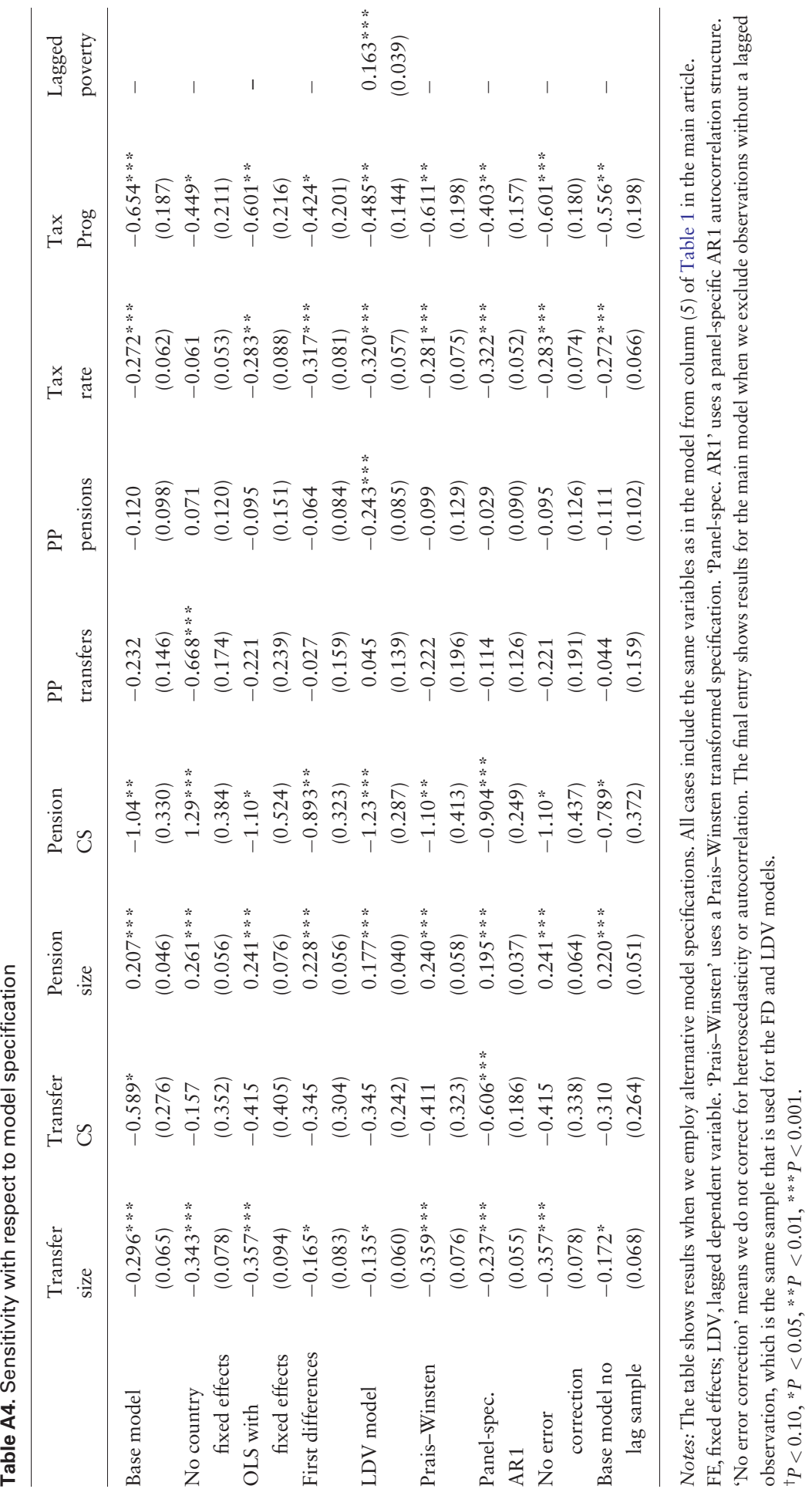




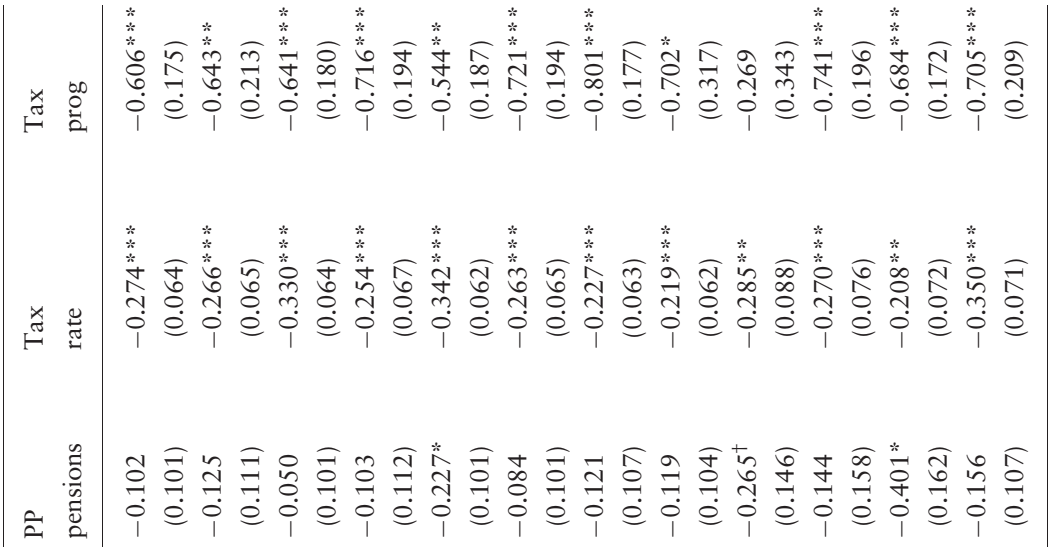

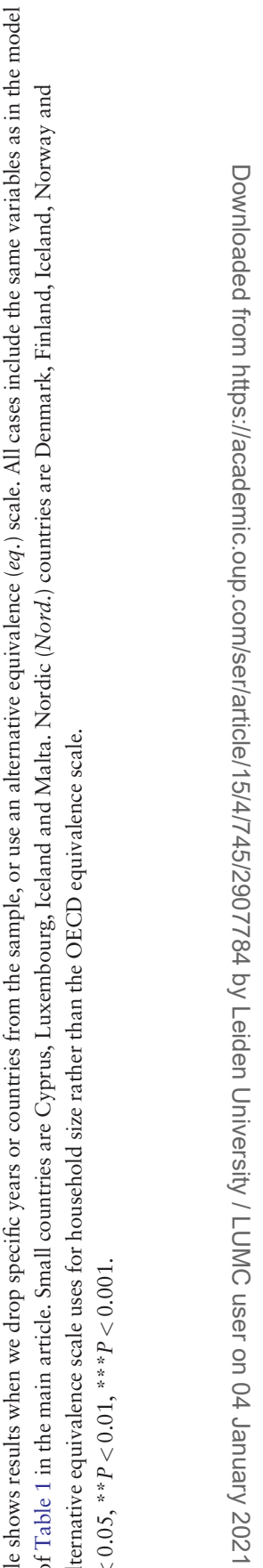

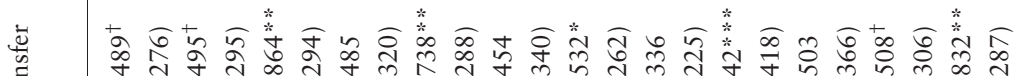

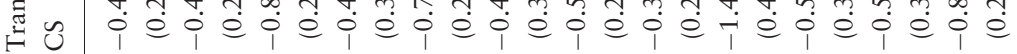

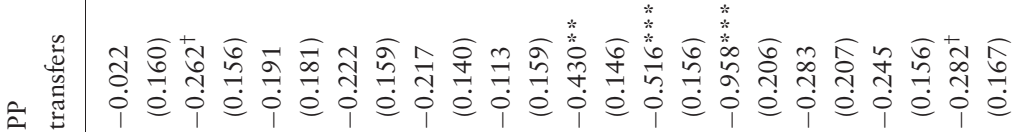

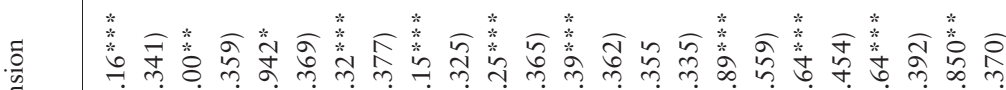

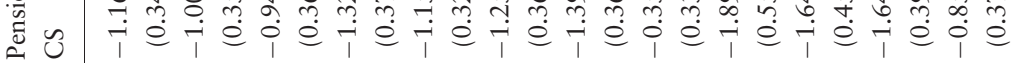

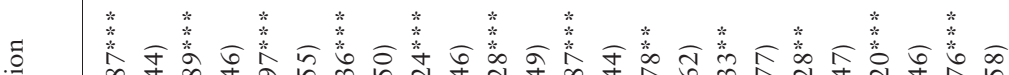
ज.

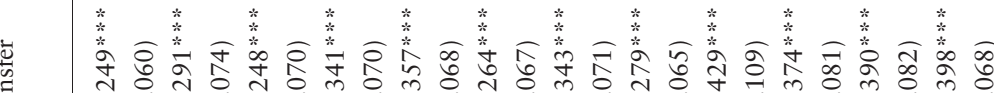

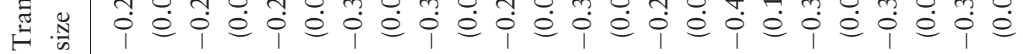


Table A6. Varying poverty thresholds

\begin{tabular}{|c|c|c|c|}
\hline & AROP 60 & AROP 50 & AROP 40 \\
\hline Transfer size & $\begin{array}{c}-0.296 * * \\
(0.065)\end{array}$ & $\begin{array}{c}-0.346 * * \\
(0.066)\end{array}$ & $\begin{array}{c}-0.189 * * * \\
(0.055)\end{array}$ \\
\hline Transfer CS & $\begin{array}{c}-0.589 * \\
(0.276)\end{array}$ & $\begin{array}{c}-1.01 * * * \\
(0.276)\end{array}$ & $\begin{array}{c}-0.427^{\dagger} \\
(0.243)\end{array}$ \\
\hline Transfer PP & $\begin{array}{r}-0.232 \\
(0.146)\end{array}$ & $\begin{array}{c}-0.288 * \\
(0.140)\end{array}$ & $\begin{array}{r}-0.079 \\
(0.144)\end{array}$ \\
\hline Pension size & $\begin{array}{l}0.207 * * * \\
(0.046)\end{array}$ & $\begin{array}{c}0.109 * \\
(0.050)\end{array}$ & $\begin{array}{c}0.050 \\
(0.046)\end{array}$ \\
\hline Pension CS & $\begin{array}{c}-1.04 * * \\
(0.330)\end{array}$ & $\begin{array}{c}-0.952 * * \\
(0.349)\end{array}$ & $\begin{array}{r}-0.460^{\dagger} \\
(0.275)\end{array}$ \\
\hline Pension PP & $\begin{array}{r}-0.120 \\
(0.098)\end{array}$ & $\begin{array}{r}-0.163^{\dagger} \\
(0.099)\end{array}$ & $\begin{array}{c}0.049 \\
(0.079)\end{array}$ \\
\hline Tax rate & $\begin{array}{c}-0.272 * * * \\
(0.062)\end{array}$ & $\begin{array}{c}-0.283 * * * \\
(0.061)\end{array}$ & $\begin{array}{c}-0.238 * * * \\
(0.054)\end{array}$ \\
\hline Tax prog & $\begin{array}{l}-0.654 * * * \\
(0.187)\end{array}$ & $\begin{array}{c}-0.557^{*} \\
(0.219)\end{array}$ & $\begin{array}{r}-0.123 \\
(0.140)\end{array}$ \\
\hline Work intensity & $\begin{array}{c}-0.842 * * * \\
(0.101)\end{array}$ & $\begin{array}{c}-0.805 * * \\
(0.103)\end{array}$ & $\begin{array}{c}-0.602 * * * \\
(0.128)\end{array}$ \\
\hline
\end{tabular}

Notes: The table shows effects of aspects of social spending and taxation on child poverty, for poverty thresholds at different percentages of median equivalized household income (either 60, 50 or $40 \%$ ). All estimates are based on the specification from Model 1. See Table 1 in the main article for an explanation on the defined explanatory variables. ${ }^{\dagger} P<0.10,{ }^{*} P<0.05, * P<0.01, * * P<0.001$. 
Table A7. Summary statistics

\begin{tabular}{|c|c|c|c|c|c|c|c|c|c|c|}
\hline & $\begin{array}{l}\text { Child } \\
\text { poverty }\end{array}$ & $\begin{array}{l}\text { Transfer } \\
\text { size }\end{array}$ & $\begin{array}{l}\text { Transfer } \\
\text { CS }\end{array}$ & $\begin{array}{l}\text { Pension } \\
\text { size }\end{array}$ & $\begin{array}{l}\text { Pension } \\
\text { CS }\end{array}$ & $\begin{array}{l}\text { Household } \\
\text { WI }\end{array}$ & $\begin{array}{l}\mathrm{PP} \\
\text { transfers }\end{array}$ & $\begin{array}{l}\text { PP } \\
\text { pensions }\end{array}$ & $\begin{array}{l}\text { Implicit } \\
\text { tax rate }\end{array}$ & $\begin{array}{l}\text { Tax } \\
\text { prog }\end{array}$ \\
\hline Austria & 14.94 & 12.04 & 1.53 & 22.88 & 0.105 & 67.86 & 2.21 & 3.09 & 40.84 & 1.77 \\
\hline Belgium & 17.25 & 13.86 & 1.23 & 15.33 & 0.052 & 70.25 & 3.10 & 10.20 & 42.76 & 1.88 \\
\hline Bulgaria & 27.30 & 6.54 & 1.28 & 17.45 & 0.334 & 66.28 & 1.67 & 1.53 & 26.88 & 1.34 \\
\hline Cyprus & 12.64 & 7.29 & 1.10 & 13.17 & 0.071 & 78.07 & 3.43 & 2.88 & 24.91 & 2.77 \\
\hline Czech Rep. & 15.04 & 10.03 & 1.33 & 17.60 & 0.104 & 71.85 & 3.17 & 3.79 & 40.08 & 1.67 \\
\hline Denmark & 10.11 & 15.92 & 0.866 & 11.76 & 0.014 & 81.57 & 3.40 & 7.21 & 36.09 & 1.31 \\
\hline Estonia & 18.87 & 8.12 & 1.66 & 13.40 & 0.170 & 72.81 & 1.80 & 2.59 & 34.86 & 1.39 \\
\hline Finland & 10.92 & 13.98 & 1.20 & 14.07 & 0.040 & 75.57 & 3.08 & 2.76 & 40.75 & 1.93 \\
\hline France & 16.61 & 11.24 & 1.43 & 23.83 & 0.062 & 74.50 & 2.99 & 2.96 & 38.85 & 1.81 \\
\hline Germany & 14.60 & 11.70 & 1.50 & 23.44 & 0.038 & 63.28 & 3.40 & 5.08 & 37.58 & 1.46 \\
\hline Greece & 23.33 & 3.44 & 0.843 & 23.76 & 0.134 & 71.56 & 3.26 & 3.84 & 31.19 & 1.66 \\
\hline Hungary & 21.20 & 16.05 & 1.55 & 25.58 & 0.186 & 64.01 & 1.81 & 1.79 & 39.49 & 1.91 \\
\hline Iceland & 11.02 & 10.11 & 1.21 & 10.91 & 0.178 & 82.99 & 3.84 & 1.91 & 34.24 & 2.13 \\
\hline Ireland & 19.60 & 19.35 & 1.27 & 11.31 & 0.122 & 55.61 & 2.53 & 2.07 & 25.83 & 6.13 \\
\hline Italy & 24.96 & 5.82 & 1.17 & 26.78 & 0.089 & 66.72 & 1.15 & 2.81 & 42.04 & 1.79 \\
\hline Latvia & 24.23 & 8.35 & 1.44 & 14.53 & 0.330 & 72.53 & 1.57 & 1.66 & 32.09 & 1.14 \\
\hline Lithuania & 23.72 & 10.19 & 1.38 & 15.62 & 0.233 & 76.16 & 2.93 & 2.25 & 13 & 1.40 \\
\hline Luxembourg & 20.66 & 11.70 & 1.42 & 19.12 & 0.089 & 70.63 & 2.33 & 2.85 & 30.90 & 2.22 \\
\hline Malta & 20.36 & 7.50 & 1.23 & 16.56 & 0.169 & 60.90 & 6.72 & 3.89 & 21.80 & 2.86 \\
\hline Netherlands & 14.21 & 9.56 & 1.00 & 17.20 & 0.037 & 70.31 & 4.99 & 5.22 & 35.26 & 1.86 \\
\hline Norway & 10.19 & 16.84 & 1.10 & 12.50 & 0.065 & 80.01 & 3.30 & 4.55 & 36.44 & 1.60 \\
\hline Poland & 23.91 & 7.12 & 1.04 & 22.91 & 0.280 & 72.14 & 3.21 & 2.24 & 32.63 & 1.15 \\
\hline Portugal & 22.21 & 6.90 & 1.11 & 22.84 & 0.140 & 77.36 & 3.74 & 3.04 & 23.56 & 2.15 \\
\hline Romania & 32.90 & 8.62 & 1.31 & 26.80 & 0.293 & 72.96 & 1.74 & 1.69 & 29.60 & 1.19 \\
\hline Slovakia & 18.57 & 8.60 & 1.29 & 20.44 & 0.252 & 77.33 & 2.90 & 2.99 & 32.25 & 1.75 \\
\hline Slovenia & 12.33 & 13.19 & 1.18 & 18.35 & 0.143 & 85.01 & 2.48 & 2.63 & 36.20 & 1.50 \\
\hline Spain & 25.78 & 6.79 & 0.946 & 18.53 & 0.128 & 69.25 & 2.75 & 3.26 & 32.58 & 2.62 \\
\hline Sweden & 12.97 & 16.23 & 1.21 & 18.71 & 0.036 & 78.57 & 2.45 & 3.47 & 41.29 & 1.64 \\
\hline UK & 21.11 & 11.55 & 1.67 & 16.54 & 0.070 & 63.18 & 3.28 & 1.91 & 26.20 & 1.54 \\
\hline
\end{tabular}

Notes: The table shows summary statistics of the main variables in our analysis. See Table 1 of the main article and Table A1 for a description of all variables. Transfer size and spending size are measured with respect to the population as a whole. Children's share (CS) are unstandardized ratios of spending distributed to the average child divided by average spending distributed to the average individual in the population. 